\title{
The Civic Voluntarism of "Custodial Citizens": Involuntary Criminal Justice Contact, Associational Life, and Political Participation
}

\author{
Michael Leo Owens and Hannah L. Walker
}

\begin{abstract}
A growing body of research explores the influence of involuntary criminal justice contact on political participation, demonstrating that all types of contact weaken political participation. We posit, however, that personal connections to civil society organizations (CSOs) moderate the negative effects of involuntary criminal justice contact on political participation, particularly political activism beyond registering to vote and voting. We test this proposition with individual-level and aggregate-level data from metropolitan and municipal Chicago. Our findings confirm a paradox of participation by custodial citizens. One, we demonstrate positive, statistically significant, and substantive effects of personal connections to CSOs on nonvoting political participation by custodial citizens. Two, the negative effects of involuntary criminal justice contact on voting participation among individuals and communities may endure, despite personal connections to CSOs, even in a state where the franchise is restored immediately after incarceration. Our study suggests that an associational account of political participation deepens our understanding of the political behavior of custodial citizens and their communities in the age of mass incarceration.
\end{abstract}

$\mathrm{n}$ the United States, citizens (and immigrant denizens) may experience unwanted, even unwarranted, contact with the criminal justice system. Categories of such criminal justice contact ${ }^{1}$ include police stops of drivers and frisks of pedestrians, arrests without formal charges and convictions, diversion from court convictions via "problem-solving" or specialized courts such as drug courts, and court convictions for misdemeanors and felonies, accompanied by sentences of incarceration, parole, or probation, along with the imposition of fees and fines by the courts. ${ }^{2}$ Criminal justice contact also includes unwanted interactions between youth and "resource officers" (i.e., police working in elementary and secondary schools), arrests and detentions of youth in juvenile or adult correctional facilities, and community supervision by and beyond "youth diversion programs." 3 The myriad of

A list of permanent links to Supplementary Materials provided by the authors precedes the References section.

Michael Leo Owens is Associate Professor of Political Science at Emory University (michael.leo.owens@emory.edu). A former member of the board of directors of the Prison Policy Initiative, Owens serves on the national advisory board of the Georgia Justice Project. Author of God and Government in the Ghetto: The Politics of Church-State Collaboration in Black America (University of Chicago Press, 2007), he is completing Prisoners of Democracy, a book manuscript about the restoration of political, social, and civil rights for formerly imprisoned people in the United States through community organizing.

Hannah L. Walker is Assistant Professor of Political Science and Criminal Justice at Rutgers University (blwalker@polisci. rutgers.edu). Walker's work explores political mobilization against the carceral state, focusing on the impact of criminal justice contact on the families and loved ones of the incarcerated.

They thank Wesley Skogan for data from the Chicago Alternative Policing Strategy, as well as Tom Ogorzalek and Tracy Burch for advice about data sources in Chicago. Additionally, they thank the Chicago Justice Project. They also thank Adam Glynn, Pierce Edwards, and the anonymous reviewers for their comments on the paper, and Michael Bernhard for his unwavering support. An earlier version of this paper was presented at the 2016 American Political Science Association meeting. 
moments for unwanted contact between citizens and the criminal justice system in the United States multiplies membership in the group scholars call "custodial citizens." They are the growing set of citizens law enforcement agencies have detained for questioning, arrested, charged, convicted, or placed under some form of correctional control for suspicion of or actual criminal behavior.

The number and rate of Americans who are custodial citizens are great, even as violent and property crime rates fall and public punitiveness abates. ${ }^{5}$ There are $110,235,200$ people in the criminal history files of the 50 states and U.S. territories, an increase of $130 \%$ from $1993 .{ }^{6}$ Nearly one in every three adults has a record of criminal arrest. ${ }^{7}$ While approximately $9 \%$ of adults have felony convictions, we generally know that the percentage of adults with misdemeanor convictions is many times larger. ${ }^{8}$ Nearly one in 34 Americans is under some form of correctional control. ${ }^{9}$ Millions of adults and juveniles who were once under correctional control for criminal convictions are now "off paper" but not necessarily fully (re) integrated into society.

Even when citizens are no longer in the unwanted grasp of carceral government, deep imprints of their criminal justice contact remain. Law enforcement agencies retain custody of, often publicize, and may permit others to monetize all information about criminal justice contact, whether slight or severe. It is contained in a vast assortment of "criminal intelligence databases, police blotters, rap sheets, court records, presentence reports, prosecutors' files, probation files, and jail and prison databases," inclusive of photographs and residential addresses. ${ }^{10}$ Thus, the half-life of criminal justice contact is immeasurable. Its effects, however, are not.

Custodial citizenship, whether from short detentions for questioning at police departments and county jails to long stretches in state or federal prisons, produces a range of negative social and labor effects for those who have had criminal justice contact. They include stigma, depression, lost earnings, unemployment, and homelessness. ${ }^{11}$ Custodial citizenship also has concomitant negative consequences for the children and families of the citizens whom law enforcement agencies have detained for questioning, arrested, charged, convicted, or placed under some form of correctional control. Examples include weakened family ties and increased behavioral problems for children. ${ }^{12}$ Custodial citizenship may even have negative effects on communities with greater residential densities of such citizens, measured for instance by residential churn, social control, and crime. ${ }^{13}$

What about the polis and politics? Custodial citizenship affects government and governance at every rung of the federalist ladder. It shapes the demographics and decisions of the legislative, executive, and judicial branches of localities, states, and the nation. ${ }^{14}$ It influences legislative reapportionment and redistricting; ${ }^{15}$ juries and electorates; ${ }^{16}$ political candidacies; ${ }^{17}$ vote margins in elections and referendums; ${ }^{18}$ distributive politics (e.g. siting of prisons and allocation of some intergovernmental transfers); ${ }^{19}$ mundane matters of public policy (e.g., measuring labor force participation and unemployment); ${ }^{20}$ and municipal revenue, particularly when city managers, police, and courts collude for exploitative revenue. $^{21}$

Furthermore, custodial citizenship is consequential to civic voluntarism by adults, particularly political participation. ${ }^{22}$ As criminal justice contact increases, intensifies, and lengthens at the individual and community levels, scholars generally observe that custodial citizens and communities with residential concentrations of them participate less in political activities, especially voting. ${ }^{23}$ Declines in voting by custodial citizens and their communities are not a function of imprisonment and felony disenfranchisement alone. Citizens who police officers have detained for questioning, for instance, report voting less, too. ${ }^{24}$ Because criminal justice contact reduces the number of people participating as voters, as well as possessing positive civic sentiments, ${ }^{25}$ it is "an important force in shaping American mass politics." 26

Rightly, scholars of political behavior, institutions, and normative theory focus on the existence, size, and causal mechanisms of the negative democratic effects of custodial citizenship. ${ }^{27}$ The study of the civic consequences of criminal justice contact is valuable-theoretically, empirically, and substantively. It increases, in particular, our understanding of the anti-democratic consequences of custodial citizenship for political attitudes and behaviors. It brings into better focus the "second face of the American state," revealing the punitive profile of "the governing institutions and officials that exercise social control and encompass various modes of coercion, containment, repression, surveillance, regulation, predation, discipline, and violence" that condition civic voluntarism while influencing other political phenomena. ${ }^{28}$ Nonetheless, as important, we argue, is the need to identify the set of factors that may attenuate the negative influence of "the state's more controlling 'second face" 29 on civic voluntarism.

While the study of the negative democratic effects of criminal justice contact invites an assortment of scholarly interventions, we widen here the disciplinary lens of the politics of criminal punishment to give greater attention to civil society. This is necessary. Deliberate consideration of civil society is atypical for political penologists interested in the democratic consequences of the American carceral state. Scholars of punishment and politics-be they Americanists, normative theorists, or comparatiststend to neglect the potential and limits of civil society organizations (CSOs) to influence political participation by custodial citizens. ${ }^{30}$ Even when they do not neglect civil society, studies of the relationship between criminal justice contact and political behavior and attitudes are limited. 
For example, they overemphasize "ex-felon serving institutions," which likely lack capacity for political mobilization. ${ }^{31}$ Yet there is reason to suspect that civil society and a variety of CSOs may mitigate the negative effects of criminal justice contact on civic voluntarism.

A large body of scholarship exists about the potential of CSOs to shape political behavior through civic skills development, community organizing, services provision, and opportunities for activism and mobilization, inclusive of participation. ${ }^{32}$ We leverage it to deduce a proposition about how and why personal connections to CSOs may positively influence political participation by adult custodial citizens, just as personal connections to CSOs routinely do for adult noncustodial citizens. ${ }^{33}$ Taking what Han calls "an organizational approach to understanding [political] activism" 34 and applying it to custodial citizens, we explore whether personal connections to one set of varied CSOsformal, tax-exempt nonprofit organizations-are associated with weaker negative effects (or positive ones) of criminal justice contact on political participation. We employ individual-level data from metropolitan Chicago on criminal justice contact, connections to CSOs, and participation and aggregate data on conviction rates, CSO densities, and political participation (i.e., voting and citizen-initiated contact with government) in municipal Chicago. Our data permit us to estimate relationships among custodial citizenship, civil society, and political forms of civic voluntarism.

Four findings are key: 1) independent of personal connections to CSOs, criminal justice contact is neither associated with voting nor non-voting; 2) custodial citizens without connections to CSOs participate less in politics via voting and nonvoting; 3) personal connections to CSOs are associated with increased nonvoting political participation among those who have had the heaviest criminal justice contact (i.e., correctional control via incarceration and community supervision); and 4) however, personal connections to CSOs may only increase some forms of political participation among custodial citizens.

\section{Criminal Justice Contact and Political Participation}

People, as the aphorism states, "participate when they can, when they want to, and when they are asked." 35 Resources, orientations, and recruitment, along with "rewards, interests, and beliefs," influence political participation. ${ }^{36}$ Institutions and policies affect political participation, too. As Mettler and Soss ${ }^{37}$ stress, "living under a given policy regime affects citizens' goals, beliefs, and identities - and hence, the possibilities and limits for future political action." However, individual-level factors associated with the likelihood of criminal justice contact build resource, efficacy, and recruitment barriers to political participation by custodial citizens. Also, the American carceral regime, buttressed primarily by white public support for punitive policies, ${ }^{38}$ including policies that exclude custodial citizens from the ballot box and public office, supplemented by punitive polices that the state, market, and civil society coproduce, ${ }^{39}$ prevents many custodial citizens from thinking and behaving as full political members of society. It is unsurprising then that research on the democratic effects of the American carceral state draws the same conclusion as scholarship on the democratic effects of the American welfare state-_"some policies draw citizens into public life and others induce passivity." 40

Aside from executing the administration of public safety and criminal corrections, criminal justice contact as a "political learning situation" 41 for custodial citizens negatively affects the political attitudes, ambitions, and activities of many custodial citizens, arguably by socializing them to see themselves as citizens with less liberty, equality, dignity, and regard than other citizens. ${ }^{42}$ Additionally, scholars observe that the relationship between criminal justice contact and electoral participation, particularly voting, is negative and the negative relationship strengthens as the grasp of criminal justice contact tightens. ${ }^{43}$ The most cited empirical study of the political attitudes and behavior of custodial citizens in the United States, for instance, estimates the likelihood of decline in voting by persons with arrests as $7 \%$, criminal convictions as $10 \%$, short stints in jail or prison as $17 \%$, and long stints of incarceration at almost one-third. ${ }^{44}$ Furthermore, in communities where the residential density of custodial citizens is higher and where more residents are removed from them through imprisonment as "coercive mobility" 45 voting is lower, too. ${ }^{46}$

Yet even when we observe that custodial citizens participate electorally at lower levels than their noncustodial counterparts, their probabilities of voting or participating politically in other ways are never zero. Additionally, some custodial citizens "double down on democratic values and practices, ${ }^{47}$ despite punitive policy designs and negative feedback of the carceral state. ${ }^{48}$ Acting as if their political participation matters and to make it so, many custodial citizens participate, defying low expectations of collective action improving their lives. ${ }^{49}$ Furthermore, criminal justice contact may reduce voting without affecting other political activities (e.g., contacting government officials, signing petitions, and demonstrating). ${ }^{50}$ Plus, because elections are infrequent and often noncompetitive-limiting their service as a strong means of democratic accountability and civic engagementcustodial citizens, like noncustodial ones, could perceive participation outside the voting booth as a better means for sharing preferences with policymakers and for achieving policy responsiveness than participation in elections. And some people prefer to participate via nonvoting political activities instead of by electoral ones. ${ }^{51}$ Therefore, borrowing Han's caution about political activism by noncustodial citizens, generally, when it comes to our 
knowledge about the political participation of custodial citizens, "we cannot assume that findings related to voting import directly to other forms of activism." $" 2$

\section{Civil Society Organizations and Custodial Citizens}

Civil society is "the primary agent of political dialogue and citizen influence" when people participate politically in the United States, particularly in cities and metropolitan areas. ${ }^{53}$ It has been since the nineteenth-century travels of Alexis de Tocqueville, who was one of the first empiricists of civil society and criminal justice contact in America. ${ }^{54} \mathrm{CSO}$ s, as de Tocqueville observed then, pave the way for political participation. It is truer in the twentyfirst century, where "every day thousands of nonprofit organizations around the country are busy organizing and creating opportunities for new associations" for individual and collective efficacy to solve public problems by (and beyond) voting and nonvoting political participation. ${ }^{55}$

\section{Civil Society Organizations as Hindrances to Participation}

Although we expect CSOs to positively affect the political participation of custodial citizens connected to them, reasons exist to be pessimistic about their influence. There has been a steady growth in the number of charitable nonprofit organizations and nonprofit advocacy organizations, which often do not mobilize clients and rely little on memberships to advance their interests. The growth of CSOs focused on charitable purposes and without mass memberships (e.g., American Society for the Prevention of Cruelty to Animals or the American Civil Liberties Union) shrinks stores of social capital for conversion to political capital. ${ }^{56}$ Such organizations "focus on maximizing the number of people involved without developing their capacity for civic action." ${ }^{57}$ It likely undermines the political utility of CSOs for citizens, ${ }^{58}$ be they custodial or noncustodial.

Also, custodial citizens, generally, are likely to reach out to and be contacted by social services $\mathrm{CSO}$ s that focus on meeting immediate needs (e.g., shelter, substance abuse recovery, employment). ${ }^{59}$ Such organizations seek to support their own persistence first and foremost. Fearing that mobilization of clients could negatively affect their finances, and misunderstanding government regulations of political activities by nonprofits, social services CSOs tend to avoid politics, limiting their level of political engagement. ${ }^{60}$

Even when $\mathrm{CSO}$ s foster political engagement, many bias their mobilization. CSOs tend to target individuals who demonstrate greater activism ${ }^{61}$ and who possess more positive social constructions and political capital. ${ }^{62}$ Given the central tendencies of the racial and class demographics of custodial citizens, the political strategies of many CSOs disregard custodial citizens and their communities, preferring to mobilize the less marginalized. ${ }^{63}$

\section{Civil Society Organizations as Pathways to Participation}

Those realities notwithstanding, it is plausible that civil society positively affects the participation of custodial citizens. Political participation has associational anchors and "organizational roots" in civil society. ${ }^{64}$ Routine functions and incentives of charities, associations, and other forms of CSOs strengthen the anchors and roots for political participation. ${ }^{65}$ Moreover, many CSOs engage in a variety of activities consequential for the political behavior of clients, volunteers, members, and other stakeholders (figure 1). ${ }^{66}$

Many CSOs, inclusive of many faith-based/religious CSOs like black churches ${ }^{67}$ and secular CSOs like labor unions, educate, train, and socialize individuals for political participation. ${ }^{68}$ They teach people to develop opinions and perceive their interests, form group consciousness and identify shared grievances, speak their concerns, and amplify their voices. ${ }^{69}$ They cultivate personal commitments to public issues and collective problem solving. ${ }^{70}$ They help individuals develop political efficacy, education, and civic skills for participation. Political engagement by individuals connected to charitable CSOs can increase from their participation in the "ordinary and routine" practices and activities of the organizations-"activity that has nothing to do with politics or public issues, can develop organizational and communications skills that are relevant for politics and thus can facilitate political activity." ${ }^{71}$ For instance, the one-on-one conversations, opportunities for public speaking, and collective problem solving of sacred and secular CSOs influence civic development, even when they are indirectly political. ${ }^{72}$ As a result, connections to CSOs by custodial citizens should reduce barriers to participation, including resource, efficacy, and recruitment barriers. $^{73}$

Beyond dispositional and institutional reasons, people participate politically because others recruit and mobilize them, ${ }^{74}$ and CSOs can channel people into opportunities for political participation. Personal connections to CSOs increase the likelihood that "political leaders" will attempt to mobilize them for political influence: "First, organizations mobilize their own members, often explicitly . . . . Second, organizations expose their members to mobilization by sympathetic politicians, activists, and other organizations." ${ }^{75}$ Thus, CSOs create bridges that connect the civic and the political spheres, which can positively affect resources, orientations, and recruitment for political participation through mobilization. ${ }^{76}$ Hence, "people who belong to associations are more likely to be mobilized and more likely to participate than people who do not belong." ${ }^{\prime 77}$ As well, some CSOs are capable of activating and mobilizing clients, constituents, and members for political participation because of "reciprocal service 


\section{Figure 1 \\ Civil society organizations pave ways for political participation}

\begin{tabular}{|c|c|c|c|c|}
\hline Political Foundation-Building & $\begin{array}{c}\text { Educate for Political } \\
\text { Participation }\end{array}$ & $\begin{array}{c}\text { Enable \& Organize } \\
\text { Political Participation }\end{array}$ & $\begin{array}{l}\text { Lobby, Advocate, \& Litigate } \\
\text { for Political Change }\end{array}$ & $\begin{array}{l}\text { Electioneer to Influence Votes } \\
\text { for Candidates \& Referendums }\end{array}$ \\
\hline $\begin{array}{l}\text { Framing and problem definitions } \\
\text { Dialogues to identify shared } \\
\text { interests, values, concerns } \\
\text { Activities to foster identities, } \\
\text { group consciousness, solidarity } \\
\text { Participatory skills-building } \\
\text { (e.g., public speaking, collective } \\
\text { critique, canvassing, etc.) } \\
\text { Community problem solving } \\
\text { activities via committees and } \\
\text { associations } \\
\text { Enrollments in public programs }\end{array}$ & $\begin{array}{l}\text { Notification of political, social, } \\
\text { and civil rights (e.g., right to vote } \\
\text { or to receive public benefits) } \\
\text { Voter education guides } \\
\text { Candidate forums } \\
\text { Policy discussion groups } \\
\text { Town halls with policymakers } \\
\text { Decennial Census education }\end{array}$ & $\begin{array}{l}\text { Voter registration } \\
\text { Voter mobilization (e.g., Get Out } \\
\text { the Vote or "Souls to the Polls" } \\
\text { events) } \\
\text { Organize or publicize legislative } \\
\text { lobby days } \\
\text { Organize or publicize petition } \\
\text { campaigns } \\
\text { Organize or publicize protests } \\
\text { Certification as an official } \\
\text { polling station for voting } \\
\text { Promote referendums }\end{array}$ & $\begin{array}{l}\text { Contact policymakers (elected } \\
\text { and appointed) to oppose or } \\
\text { support existing or new } \\
\text { legislation, laws, regulations, } \\
\text { rules, ordinances, services, } \\
\text { directives, etc. via direct and } \\
\text { grassroots lobbying and } \\
\text { advocacy } \\
\text { File court cases }\end{array}$ & $\begin{array}{l}\text { Recruit candidates } \\
\text { Appeal to voters to retain or } \\
\text { change who holds public office } \\
\text { Create PACs, parties, and other } \\
\text { formal political associations } \\
\text { "Express advocacy" and "Issue } \\
\text { Advocacy" }\end{array}$ \\
\hline Perceived as least political & & & $\longrightarrow$ & Perceived as most political \\
\hline
\end{tabular}

provision" that produces patron/client relationships that benefit organizations, their clients, and even political elites. $^{78}$

Evidence is strong and consistent that CSOs, even human services CSOs, can inform, activate, and mobilize marginalized people. CSOs help them overcome the greater resource, efficacy, and recruitment barriers to participation that they face relative to people who are not marginalized. ${ }^{79}$ The provision and shaping of routine opportunities for engagement often allow CSOs to demonstrate that collective action produces symbolic and substantive rewards for marginalized people. ${ }^{80}$ Accordingly, civic voluntarism among lower SES individuals is higher in communities with more and stronger CSOs than in neighborhoods with fewer and weaker ones. ${ }^{81}$

Furthermore, CSOs are central to social welfare delivery in communities with high rates of custodial citizens. Again, it is unusual for human services CSOs to explicitly emphasize political action and mobilization. Nevertheless, some CSOs deliberately enable custodial citizens to develop and practice political resistance. ${ }^{82}$ Moreover, some CSOs exist to politically activate and mobilize custodial citizens and their communities. ${ }^{83}$ They provide custodial citizens with a greater sense of civic and political worth for fostering "new citizenship" and political participation through associational life (see figure 2). ${ }^{84}$

In sum, CSOs can perform multiple roles that bear on political participation. From fostering group consciousness, solidarity, and social capital to spending resources to influencing elections, CSOs can develop the democratic capacities, sentiments, and activities of citizens, custodial or otherwise. Accordingly, there are more reasons than not to expect that personal connections between custodial citizens and CSOs mitigate- and possibly reverse-the negative effects of criminal justice contact on political participation by custodial citizens. Therefore, we predict that custodial citizens with personal connections to CSOs are more likely to participate by voting and nonvoting political activities than custodial citizens without personal connections to CSOs.

\section{Data, Measures, and Methods}

We test our prediction about the influence of criminal justice contact and CSOs on the political participation of custodial citizens with individual and aggregate-level data from the Chicago metropolitan area. Chicago is more alike than different from many major metropolitan areas and central cities. "Chicago is not absolutely average, to be sure ... . But Chicago has faced the dynamics that have confronted old major cities in the country-growth, decline, crime, and boom times. In this sense Chicago [is] both unique and broadly representative, grounded in a thoroughly documented history and context that helps us understand key patterns." ${ }^{85}$ Moreover, trends in criminal justice contact in Illinois and Chicago "are broadly consistent with trends in crime and incarceration throughout the United States." 86

Illinois is neither high nor low regarding correctional control: The rate of adults incarcerated, paroled, or on probation is $1: 38$, placing Illinois thirty-fourth among 


\section{Figure 2 \\ Redeeming citizenship by/for people with criminal justice contact}

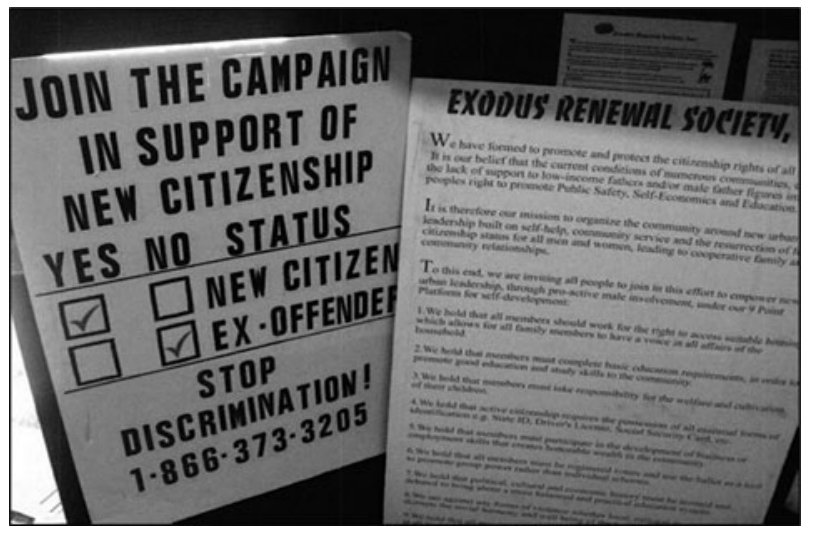

Photo credit: Michael Leo Owens

the fifty states. Chicago, its key metropolitan area and central city, has a large subpopulation of custodial citizens and is the primary destination for the return of persons released from correctional institutions, inclusive of the local Cook County Jail. For instance, of the approximately 39,000 people annually released from prison in Illinois, $51 \%$ of them reside in the city of Chicago, mainly in seven of 77 neighborhoods, marked by "concentrated disadvantage" in terms of poverty and unemployment rates. ${ }^{87}$

Additionally, restrictions on voting by people under correctional control via prison, jail, parole, or probation with felony convictions in Chicago are comparable to those covering custodial citizens in most metropolitan areas (and states) in the United States. Under Illinois law, custodial citizens are only disenfranchised while incarcerated. Like those in fifteen other states and the District of Columbia, custodial citizens in Chicago who are on parole or probation (i.e., most Chicagoans under correctional control) may vote. Custodial citizens in Illinois may vote, too, while awaiting trial, be they jailed or bonded.

Most important, because of the 2014 Chicago Area Study (CAS), there is adequate survey data permitting estimates of the relationship among criminal justice contact, personal connections to CSOs, and political participation. The CAS, which our online appendix details, surveyed 1,294 respondents, including an oversample of blacks and Latinos, living in the central city and suburbs of metropolitan Chicago. ${ }^{88}$ Of course, we know the statistical limits of self-reported data relative to strengths of administrative data on criminal justice contact and political participation. ${ }^{89}$ We lack the latter, however, for Chicago or Illinois, particularly for measures of personal connections to CSOs and participation beyond registering to vote and voting.
In addition to the CAS, we collected aggregate data on criminal justice contact, CSOs, and political participation in the city of Chicago at the level of neighborhood beats of the Chicago Police Department. We matched a set of measures of criminal justice contact, CSO density, and voting and nonvoting political participation to each police beat. Police beats, which are our units of supplemental analysis $(\mathrm{N}=270)$, allowed us to leverage an important form of nonvoting political participation in Chicago, namely attendance at police beat meetings ${ }^{90}$ (and to address concerns about selection and response bias associated with surveys like the CAS). ${ }^{91}$

Generally, Chicago is a city of public meetings, as is true of many cities. ${ }^{92}$ In particular, it is a city that uses public meetings as vehicles for citizen contact with government officials. The police beat meetings of the Chicago Alternative Policing Strategy (CAPS) are one important set of meetings in Chicago. ${ }^{93}$ At least 53,000 police beat meetings were held from 1995 through 2016, with total annual attendance ranging from 21,000 to approximately 60,000 people. ${ }^{94}$ The meetings occur at least once each quarter, offering residents opportunities for faceto-face interaction with law enforcement and other government officials, where they make requests related to policing and other municipal services. The meetings allow municipal agencies and citizens to collaborate to coproduce improved police-community relations and greater public safety. "With the exception of elections, it is difficult to identify a municipal activity of any kind attracting similar levels of civic participation-anywhere in the country." ${ }^{95}$ Furthermore, "Chicago's policing program has helped to even out the opportunities to participate in community governments, with the greatest increase in collective participation by African-Americans. ${ }^{\prime 96}$

\section{CAS Survey-Criminal Justice Contact and Personal Connections to Civil Society Organizations}

Our key independent variables are criminal justice contact and personal connections to CSOs. Our measures of criminal justice contact come from a CAS question: We are interested in how much contact people have had with the police. In the past five years, have you... (please select all that apply)—been questioned by the police for any reason, been on probation or parole, served time in jail andlor prison. Eleven percent of respondents indicated that the police had questioned them and five percent reported being under correctional control in the past. We model selfreported levels of criminal justice contact in the past five years with dummy variables (Yes $=1,0=\mathrm{No}$ ) for detained (i.e., questioned by the police) and correctional control (i.e., prison, parole, or probation). The CAS data do not permit a refined assessment of the length of time either under correctional control or length of time since criminal justice contact. 
The CAS queried respondents about their personal connections to CSOs: Some people participate in groups and organizations while others do not. Do you currently belong to, volunteer with, attend meetings of, or pay dues for any of the following types of groups? Types of groups included: (1) religious group; (2) neighborhood or community organization; (3) labor union; (4) a professional organization; (5) an ethnic/cultural organization; (6) political organization that focuses on a specific cause; (7) political party; (8) civic organization (e.g., Rotary Club); (9) other; and (10) none of these. Initially, we coded the types of CSOs that respondents identified having personal connections to into six dummy variables: religious, community, ethnic, labor, political, and other. We tested the independent effects of these dichotomous variables. Ultimately, we exclude them because the CAS provided insufficient data for rigorous tests and robust results. Consequently, our measure of personal CSO connections is a dichotomous variable, measuring personal or direct participation in any type of group (Yes $=1$, No $=0$ ). Forty-two percent of respondents reported connections to CSOs. Although we know that higher levels of personal involvement in organizations produce greater personal involvement "in governmental politics" and other arenas of political participation such as elections, ${ }^{97}$ the CAS did not measure the degree of personal involvement in CSOs.

We use two measures of voting from the CASwhether a respondent was registered to vote and whether they reported voting in the 2012 presidential election. Among registered voters in the CAS, $89 \%$ reported voting in $2012 .{ }^{98}$ We measure nonvoting political participation by self-reports of seven political activities, inclusive of a few electoral activities besides voting, respondents performed within 12 months prior to the survey: (1) signed a petition; (2) shared political information via social media; (3) attended a protest; (4) wrote a letter to an elected official; (5) donated to a political cause; (6) volunteered for a political campaign; or (7) issued a political opinion publicly in the form of an op-ed or calling into a radio show. We scaled the items, creating a conventional nonvoting political participation index. It ranges from zero to seven, with a mean of 1.53 activities. ${ }^{99}$ The variety of activities in our index raises the possibility that one activity (e.g., protesting) drives observed relationships between criminal justice contact and nonvoting political participation. To evaluate the appropriateness of the use of the index we model the independent effects of each type of criminal justice contact and CSO connections on each item in the index. Figure 3 displays the marginal effects.

There is no evidence that correctional control negatively correlates with any item in the nonvoting political participation index. Instead, we observe that criminal justice contact positively correlates with contacting a government official, volunteering, and donating money to a cause. It is otherwise unrelated to nonvoting political participation. Figure 3 also does not reveal that any one activity or type of activity underlies a positive association between police detentions for questioning and nonvoting political participation. Finally, figure 3 illustrates that CSO connections statistically increase participation in all activities but one-sharing opinions on TV, radio, or in a newspaper. Given the general absence of a pattern of criminal justice contact affecting nonvoting political participation, we retain the seven-item scale as our measure of political participation beyond voting and registering to vote.

We control for race, gender, age, education, income, political interest, efficacy, party identification, marriage, and unemployment. The CAS stratified its sample by race. It did not stratify by other characteristics cooccurring with criminal justice contact (e.g., income and education). There may be an underrepresentation of respondents with criminal justice contact because of under-sampling some subpopulations or respondents concealing criminal justice contact. To mitigate potential data biases arising from sampling error, we apply weights to the CAS data where possible, using U.S. Census Bureau estimates of the demographics of the Chicago metropolitan area. ${ }^{100}$

\section{Aggregate Data-Criminal Justice Contact and Density of Civil Society Organizations}

We rely on a unique set of public records of criminal convictions to measure criminal justice contact at the community level. Our data from the Chicago Justice Project (CJP), originally collected by the Office of the Chief Judge of the Circuit Court of Cook County (CCCC), includes records of criminal convictions and sentences by the Criminal Division of the CCCC between 2005 and $2009{ }^{101}$ The records are cases the State's Attorney brought against 173,204 individuals it charged with felonies. For our measure and analysis, we retained felony conviction records for residents of the city of Chicago, relying on physical home address the court provided for each defendant. We successfully geocoded $90 \%$ of the 42,200 cases in the dataset $(\mathrm{N}=37,980)$. We corrected for an extremely right-skewed raw rate of felony convictions by logging conviction rates ( $\log$ (Convictions)). ${ }^{102}$

We also measure density of CSOs at the community level, which somewhat parallels or proxies for personal connections to CSOs. Extant research on civil society, especially in Chicago, tells us important things about the measure, beyond the fact that it is an indicator of the organizational foundation and milieu of communities. ${ }^{103}$ First, CSO densities are relatively stable by decade. Second, CSO density is positively correlated with events for civic engagement and action, especially "charity events, community festivals, public meetings, recreational activities, and workshops," and political protests and rallies. ${ }^{104}$ Third, 


\section{Figure 3}

Marginal effects of criminal justice contact on participation

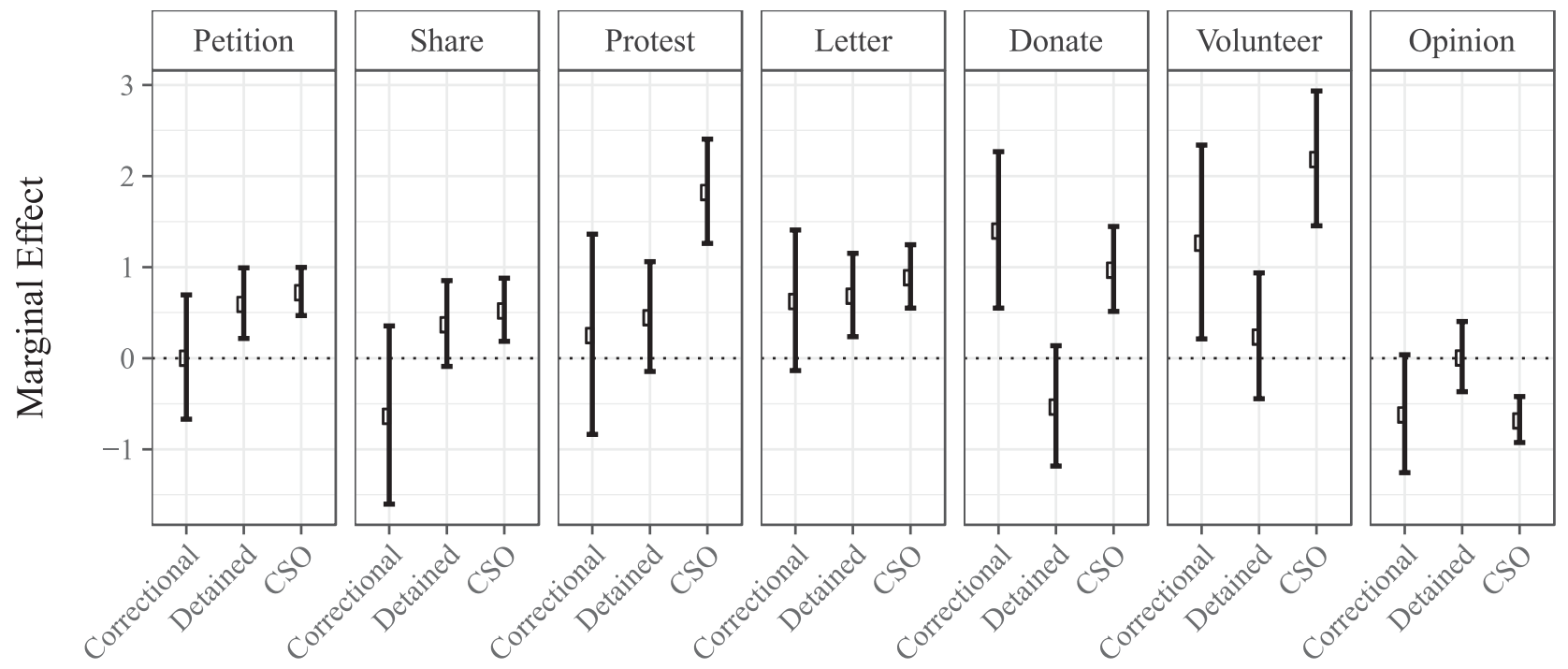

Notes: The figure reflects the marginal effect of correctional control, being detained by the police, and CSO connections on each item in the nonvoting participation index. Coefficients reflect fully specified models, located in tables A6 and A7 of the online appendix.

CSO density is a strong predictor of the propensity of "collective action" in or by neighborhoods in Chicago. 105

We constructed our CSO density measure from the Exempt Organizations Business Master File Extracts ${ }^{106}$ of the Internal Revenue Service (IRS). The IRS identifies all active, tax-exempt, CSOs in the United States with annual incomes greater than $\$ 25,000$ that are registered with the federal government and are required to file annual financial disclosure reports. Also, the IRS dataset classifies all nonprofit organizations by missions, describes the types of services they provide, and identifies their physical addresses. We chose all CSOs operating in Chicago that the IRS categorized as 501(c)(3), 501(c)(4), 501(c)(5), 501(c)(7), and 501(c)(9) nonprofit organizations $(\mathrm{N}=13,932) .{ }^{107}$ We aggregated CSOs to police beats, standardizing counts by rates of CSOs per 1,000 people. Like the convictions data, densities of CSOs skewed rightward, ${ }^{108}$ requiring logging CSO densities $(\log (C S O))$.

We use two measures of nonvoting political participation that involve contacting public officials, either of a community or particularistic bent. ${ }^{109}$ The first measure is a multiyear variable of public attendance at police beat meetings, using proprietary CAPS data on the number of civilian attendees per beat per month from 2013 through 2015. ${ }^{110}$ We regard attendance at police beat meetings as an aggregate equivalent of survey items measuring attendance at community or political meetings. We calculated both the mean average attendance across all years by police beat and rates of meeting attendance per 1,000 people.
Attendance rates ranged from .55 to 36.2, with a mean of 3.6.

Influenced by a resurgence in the study of nonvoting political participation, particularly citizen-initiated contact with government, ${ }^{111}$ our second measure of contact operationalizes nonvoting political participation by instances of requests for nonemergency services from the city of Chicago via its 24-hour municipal 311 call system. ${ }^{112} \mathrm{We}$ treat a 311 call as an analog to the conventional survey measure of contacting a public official. Furthermore, 311 callers demonstrate "custodianship" for the commons, contribute to the maintenance of public goods, and reveal a "civic disposition - that is manifest in a broader pattern of political participation, including behaviors like voting and volunteering." 113 Theoretically, variation in criminal justice contact and CSO densities should influence 311 calls. If higher levels of criminal justice contact, for instance, degrade trust in government, whereby less engagement with political life results, eroded trust should diminish the propensity of communities to contact governments to address neighborhood issues. ${ }^{114}$ We geocoded all 311 calls in Chicago in $2014(\mathrm{~N}=584,644)$ and calculated calls per 1,000 people at the level of police beats. Rates ranged from 1.9 calls to 221.1 calls, averaging 87.5 calls. ${ }^{115}$

Turning to voting participation in the municipality of Chicago, our two measures are turnout by registered voters in the 2014 Illinois general election (2014 voter turnout) and voter turnout in the 2015 mayoral election (2015 voter turnout), derived from electoral precinct-level data from the municipal Board of Election Commissioners. 
Table 1

Effects of criminal justice contact on political participation

\begin{tabular}{|c|c|c|c|}
\hline & Registered to Vote ${ }^{a}$ & Voted in 2012 & Nonvoting Political Participation $^{\mathbf{b}}$ \\
\hline Correctional control & $\begin{array}{l}-0.131 \\
(0.586)\end{array}$ & $\begin{array}{l}-0.881 \\
(0.485)\end{array}$ & $\begin{array}{c}0.061 \\
(0.122)\end{array}$ \\
\hline Detained by police & $0.754^{*}$ & $\begin{array}{l}0.099 \\
(0.345)\end{array}$ & $0.191^{\star *}$ \\
\hline CSO connection & $\begin{array}{l}0.683^{* *} \\
(0.234)\end{array}$ & $\begin{array}{c}0.549^{*} \\
(0.245)\end{array}$ & $\begin{array}{l}0.293^{\star \star \star} \\
(0.050)\end{array}$ \\
\hline Black & $\begin{array}{c}0.289 \\
(0.396)\end{array}$ & $\begin{array}{c}0.439 \\
(0.383)\end{array}$ & $\begin{array}{l}-0.077 \\
(0.075)\end{array}$ \\
\hline Latino & $\begin{array}{l}-0.599^{\star} \\
(0.265)\end{array}$ & $\begin{array}{l}-0.120 \\
(0.307)\end{array}$ & $\begin{array}{c}0.098 \\
(0.066)\end{array}$ \\
\hline Other race & $\begin{array}{l}-0.572 \\
(0.342)\end{array}$ & $\begin{array}{l}-0.578 \\
(0.395)\end{array}$ & $\begin{array}{l}-0.078 \\
(0.098)\end{array}$ \\
\hline Political interest & $\begin{array}{c}0.053 \\
(0.108)\end{array}$ & $\begin{array}{l}0.321^{\text {** }} \\
(0.116)\end{array}$ & $\begin{array}{l}0.166^{\star \star \star} \\
(0.026)\end{array}$ \\
\hline Political efficacy & $\begin{array}{l}0.472^{\star *} \\
(0.151)\end{array}$ & $\begin{array}{c}0.261 \\
(0.161)\end{array}$ & $\begin{array}{l}0.106^{\star *} \\
(0.037)\end{array}$ \\
\hline Education & $\begin{array}{l}-0.009 \\
(0.130)\end{array}$ & $\begin{array}{c}0.195 \\
(0.136)\end{array}$ & $\begin{array}{c}0.069^{*} \\
(0.030)\end{array}$ \\
\hline Female & $\begin{array}{c}0.075 \\
(0.224)\end{array}$ & $\begin{array}{c}0.111 \\
(0.239)\end{array}$ & $\begin{array}{l}-0.007 \\
(0.049)\end{array}$ \\
\hline Age: $18-34$ & $\begin{array}{l}-0.525^{\star} \\
(0.249)\end{array}$ & $\begin{array}{l}-0.126 \\
(0.272)\end{array}$ & $\begin{array}{c}0.147^{\star} \\
(0.061)\end{array}$ \\
\hline Age: $65+$ & $\begin{array}{r}1.273^{\star} \\
(0.506)\end{array}$ & $\begin{array}{r}0.873^{*} \\
(0.423)\end{array}$ & $\begin{array}{l}-0.067 \\
(0.067)\end{array}$ \\
\hline Democrat & $\begin{array}{c}0.308 \\
(0.332)\end{array}$ & $\begin{array}{c}0.489 \\
(0.335)\end{array}$ & $\begin{array}{l}-0.014 \\
(0.066)\end{array}$ \\
\hline Independent & $\begin{array}{l}-0.572 \\
(0.301)\end{array}$ & $\begin{array}{l}-0.463 \\
(0.307)\end{array}$ & $\begin{array}{l}-0.055 \\
(0.066)\end{array}$ \\
\hline Income & $\begin{array}{c}0.163^{\star} \\
(0.079)\end{array}$ & $\begin{array}{l}0.267^{\star * *} \\
(0.089)\end{array}$ & $\begin{array}{l}-0.015 \\
(0.017)\end{array}$ \\
\hline Married & $\begin{array}{l}-0.347 \\
(0.250)\end{array}$ & $\begin{array}{c}0.142 \\
(0.274)\end{array}$ & $\begin{array}{c}0.039 \\
(0.056)\end{array}$ \\
\hline Unemployed & $\begin{array}{l}-0.199 \\
(0.275)\end{array}$ & $\begin{array}{l}-0.608^{*} \\
(0.289)\end{array}$ & $\begin{array}{c}0.132 \\
(0.074)\end{array}$ \\
\hline Constant & $\begin{array}{c}0.546 \\
(0.609)\end{array}$ & $\begin{array}{l}-0.925 \\
(0.678)\end{array}$ & $\begin{array}{l}-0.749^{\star \star \star} \\
(0.152)\end{array}$ \\
\hline Observations & 1,229 & 1,140 & 1,229 \\
\hline $\begin{array}{l}\text { Log Likelihood } \\
\text { AIC }\end{array}$ & $\begin{array}{r}-335.595 \\
707.191\end{array}$ & $\begin{array}{r}-293.608 \\
623.216\end{array}$ & $\begin{array}{r}-1,699.86 \\
3,435.71\end{array}$ \\
\hline
\end{tabular}

Notes: ${ }^{2}$ We model registered to vote and voted in 2012 with logistic regression.

bWe model nonvoting political participation with Poisson regression. A dispersion test, using the $R$ package "AER," yielded an estimate of .662, suggesting the data are not burdened by overdispersion.

${ }^{*} \mathrm{p}<.05 ;{ }^{* *} \mathrm{p}<.01 ;{ }^{* \star *} \mathrm{p}<.001$.

Estimated mean voter turnout for the 2014 election is $47 \%$ and $38 \%$ for 2015 . Descriptive statistics and correlation matrices for all variables in our individual-level and community-level analyses are available from tables A1-A4 of the online appendix. ${ }^{116}$

\section{Empirical Analyses and Results}

Individual-Level Analysis

To get a baseline estimate of the relationship between criminal justice contact and political participation, we assess the relationships of criminal justice contact and measures of voting participation and nonvoting participation at the individual level. We would expect, based on extant studies, that voting participation by custodial citizens would be lower than voting participation by noncustodial citizens, with more intense criminal justice contact being associated with greater reductions in voting. The results in table 1 partially support the expectations.

More intense criminal justice contact, measured by correctional control via imprisonment or jailing or 
community supervision through parole or probation, is negatively associated with individuals being registered to vote and having voted. However, the relationship is not statistically significant. Conversely, and curiously, being detained by the police for questioning is associated with an increased likelihood of voter registration. Yet, like having been under correctional control, we failed to observe any association between police detentions for questioning and voting in 2012.

Turning to the effect of contact on nonvoting participation, we would expect a positive relationship, as most previous studies conclude. As table 1 shows, the results from Chicago partially support the expectation. ${ }^{117}$ Respondents who report that the police had detained them for questioning are likely to have greater levels of nonvoting political participation. The finding confirms results from other studies that show less intense criminal justice contact may increase nonvoting participation. ${ }^{118}$ Yet there is no evidence from Chicago that incarceration and community supervision increase or decrease nonvoting participation. This, too, is relatively consistent with prior research. $^{119}$

So far, we have evidence that criminal justice contact may have varied effects on voting and nonvoting political participation. The positive associations we observe for civic voluntarism through personal connections to CSOs-controlling for other factors, including correctional control-are, however, consistent for voting and nonvoting participation (table 1). The relationship achieves statistical significance across all three models. Personal connections to CSOs are associated with increased participation, as we theorized. This strengthens our expectation that personal connections to CSOs are positively associated with voting and nonvoting political participation by custodial citizens.

Turning our attention to examining the moderating effect of personal connections to CSOs on the political participation of individuals with criminal justice contact, we explore the relationship between criminal justice experiences with personal connections to CSOs. The results in table 2 suggest that personal connections to $\mathrm{CSO}$ correlate with a greater propensity of nonvoting participation by custodial citizens, relative to those with criminal justice contact who lack CSO connections. The interaction of correctional control and personal connections to CSOs produced results that accord with our hypothesis about political participation beyond registering to vote and voting. Personal connections to CSOs are positively related to greater nonvoting political participation by people who have been under correctional control, after controlling for factors that conventionally correlate with civic voluntarism.

To better interpret the relationships among criminal justice contact, connections to CSOs, and nonvoting political participation, we calculated the expected score on the nonvoting political participation index by degree of criminal justice contact. We did this for custodial citizens with and without connections to CSOs. Regardless of the degree of contact, personal connections to CSOs improve nonvoting participation by custodial citizens relative to those lacking connections to CSOs (figure 4). Absent CSO connections, criminal justice contact diminishes the expected level of nonvoting political participation. Those without criminal justice contact and without CSO connections have an expected score of 1.25 activities on the index. The expected score on the index shrinks to one activity for those who have been under correctional control and lack CSO connections. Among similarly situated custodial citizens with CSO connections who have been under correctional control, however, the expected score on the index increases to 2.25 activities. ${ }^{120}$

Remarkably, the size of the positive association of personal connections to CSOs on nonvoting political participation is larger for those with criminal justice contact than for those without it. For noncustodial citizens, personal connections to CSOs improve nonvoting political participation by about .3 political activities. Among Chicagoans the police have detained, CSO connections improve the expected score on the index by about .6 political activities. Personal connections to CSOs also increase the expected score by 1.25 political activities among respondents who have experienced some form of correctional control. Moreover, the expected value of nonvoting participation for custodial citizens with personal ties to CSOs exceeds that of their counterparts without criminal justice contact.

Nevertheless, personal connections to CSOs appear to not moderate the depressive effects of criminal justice contact on voting. Our finding, which is important, may reflect that the material and attitudinal barriers to voting custodial citizens face remain high despite any capacity of $\mathrm{CSO}$ so pave the way for voting. Even in places like metropolitan Chicago, where all custodial citizens are eligible to vote, and even as their connections to CSOs may ease participation in other forms of civic engagement, barriers to voting may remain. Lastly, the results reveal that personal connections to CSOs by custodial citizens the police have detained for questioning may not be statistically significant for voting or nonvoting political participation. $^{121}$

One implication of our findings is that the empirical claims of the literature about the negative democratic effect of the carceral state are too general to adequately describe civic voluntarism by custodial citizens. Certainly, custodial citizens may withdraw from or neglect voting. Nonetheless, many continue to participate outside the ballot box, especially when they are connected to CSOs. Moreover, some custodial citizens will begin participating beyond voting because they have personal connections to CSOs. Such connections may make their participation more likely and frequent because the $\mathrm{CSO}$ s create 
Table 2

The interactive effects of contact and CSO connections on forms of participation

\begin{tabular}{|c|c|c|c|}
\hline & Registered to Vote ${ }^{a}$ & Voted in 2012 & Nonvoting Political Participation ${ }^{\mathbf{b}}$ \\
\hline Correctional control & $\begin{array}{l}-0.160 \\
(0.662)\end{array}$ & $\begin{array}{l}-1.565^{\star \star} \\
(0.574)\end{array}$ & $\begin{array}{l}-0.213 \\
(0.196)\end{array}$ \\
\hline CSO connection & $\begin{array}{r}0.601^{*} \\
(0.243)\end{array}$ & $\begin{array}{l}0.551^{*} \\
(0.273)\end{array}$ & $\begin{array}{l}0.255^{\star \star \star} \\
(0.054)\end{array}$ \\
\hline Detained by police & $\begin{array}{c}0.533 \\
(0.419)\end{array}$ & $\begin{array}{c}0.519 \\
(0.471)\end{array}$ & $\begin{array}{c}0.131 \\
(0.112)\end{array}$ \\
\hline Correctional control ${ }^{\star} \mathrm{CSO}$ connection & $\begin{array}{c}0.356 \\
(1.483)\end{array}$ & $\begin{array}{c}2.518 \\
(1.389)\end{array}$ & $\begin{array}{r}0.519^{*} \\
(0.249)\end{array}$ \\
\hline Detained ${ }^{*} \mathrm{CSO}$ connection & $\begin{array}{c}1.027 \\
(1.025)\end{array}$ & $\begin{array}{l}-0.911 \\
(0.676)\end{array}$ & $\begin{array}{c}0.109 \\
(0.139)\end{array}$ \\
\hline Observations & 1,229 & 1,140 & 1,229 \\
\hline Log Likelihood & -335.809 & -290.046 & $-1,696.76$ \\
\hline AIC & 711.619 & 620.092 & $3,433.52$ \\
\hline
\end{tabular}

opportunities for education, activation, and mobilization, as they do for noncustodial citizens.

\section{Aggregate-Level Data}

Based on our results from the individual-level analysis, combined with the broader empirical findings in the literature on the political behavior and attitudes of custodial citizens, we explore a simple set of predictions about criminal justice contact at the community-level: greater criminal justice contact is associated with decreases in electoral participation, measured by voting and greater criminal justice contact is associated with increases in nonvoting political participation. Recall that our aggregate criminal justice contact measure is felony conviction rate. It is, as table 3 displays, statistically associated with lower turnout in the 2015 mayoral election. We logged the rate of felony convictions such that the coefficient estimate is interpreted as the absolute change in 2015 turnout given a percent change in felony convictions. Thus, a $5 \%$ increase in the felony conviction rate decreases expected voter turnout at the community-level in 2015 by approximately four percentage points. Also, while the relationship is not statistically significant, the felony conviction rate is negatively associated with the 2014 general election turnout.

Independent of CSO density, the rate of felony convictions is associated with increased nonvoting political participation, measured by 311 calls. Moving from the minimum value of felony conviction rate (.018) to its mean value (7.5) increases the rate of nonemergency calls in Chicago from 24 calls per 1,000 residents in police beats to just over 100 calls. Similarly, the felony conviction rate positively relates to meeting attendance, with the relationship approaching statistical significance. The positive effect that may exist between the felony conviction rate on both types of nonvoting political participation perhaps indicates neighborhood disorder and maybe lower (or higher) levels of community efficacy. ${ }^{122}$ That would mean felony conviction rates co-occur with needs for nonemergency assistance/ antagonistic policing practices in need of redress. ${ }^{123}$

Furthermore, one would expect that the scale of CSO presence in communities would particularly influence

\section{Figure 4 \\ The impact of criminal justice contact and CSO connections on participation}

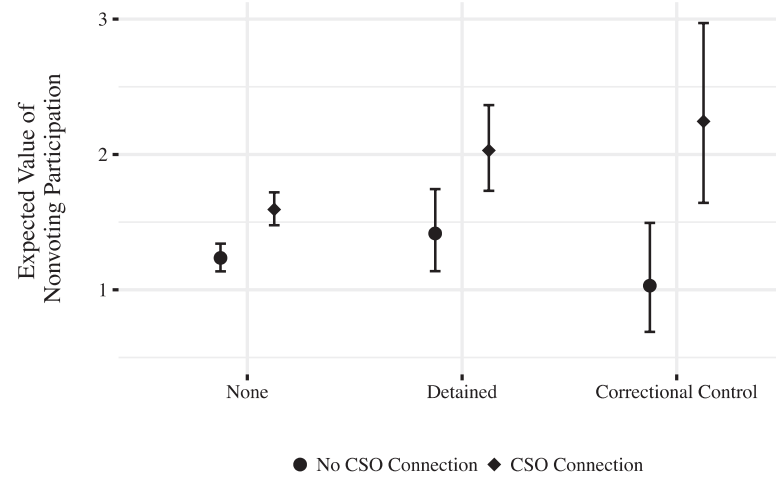

Notes: The figure reflects the interactive effect of criminal justice contact and CSO connections on participation among CAS respondents in the Chicago Metropolitan Area. Expected values derived from the nonvoting political participation model (refer to table 2). 
Table 3

Effect of conviction rates and CSO densities on voting and nonvoting participation

\begin{tabular}{|c|c|c|c|c|}
\hline & 2014 Voter Turnout & 2015 Voter Turnout & Meeting Attendance & 311 Calls \\
\hline Log (convictions) & $\begin{array}{l}-0.006 \\
(0.003)\end{array}$ & $\begin{array}{l}-0.008^{\star} \\
(0.003)\end{array}$ & $\begin{array}{c}0.494 \\
(0.306)\end{array}$ & $\begin{array}{l}11.137^{\star * \star} \\
(2.662)\end{array}$ \\
\hline Log (CSOs) & $\begin{array}{c}0.004 \\
(0.004)\end{array}$ & $\begin{array}{l}-0.002 \\
(0.004)\end{array}$ & $\begin{array}{l}0.852^{\star *} \\
(0.325)\end{array}$ & $\begin{array}{l}9.391^{\star \star} \\
(3.242)\end{array}$ \\
\hline$\% 18-34$ & $\begin{array}{l}-0.347^{* * *} \\
(0.062)\end{array}$ & $\begin{array}{l}-0.296^{\star \star *} \\
(0.063)\end{array}$ & $\begin{array}{c}0.196 \\
(4.872)\end{array}$ & $\begin{array}{c}10.168 \\
(48.693)\end{array}$ \\
\hline$\% 65+$ & $\begin{array}{l}0.297^{* *} \\
(0.108)\end{array}$ & $\begin{array}{l}0.598^{\star \star \star} \\
(0.109)\end{array}$ & $\begin{array}{l}-1.117 \\
(8.442)\end{array}$ & $\begin{array}{l}23.671 \\
(84.266)\end{array}$ \\
\hline$\%$ black & $\begin{array}{l}0.082^{* \star *} \\
(0.018)\end{array}$ & $\begin{array}{l}-0.029 \\
(0.019)\end{array}$ & $\begin{array}{l}-3.290^{\star} \\
(1.438)\end{array}$ & $\begin{array}{c}24.780 \\
(14.350)\end{array}$ \\
\hline$\%$ Latino & $\begin{array}{l}-0.053^{*} \\
(0.025)\end{array}$ & $\begin{array}{r}0.057^{\star} \\
(0.025)\end{array}$ & $\begin{array}{l}-4.978^{\star} \\
(1.946)\end{array}$ & $\begin{array}{l}53.152^{\star *} \\
(19.354)\end{array}$ \\
\hline$\%$ College graduate & $\begin{array}{l}0.287^{\star \star \star} \\
(0.039)\end{array}$ & $\begin{array}{l}0.175^{\star * *} \\
(0.040)\end{array}$ & $\begin{array}{l}-7.714^{\star} \\
(3.190)\end{array}$ & $\begin{array}{l}-78.220^{\star} \\
(30.894)\end{array}$ \\
\hline$\%$ Poor & $\begin{array}{l}-0.022 \\
(0.055)\end{array}$ & $\begin{array}{l}-0.087 \\
(0.056)\end{array}$ & $\begin{array}{c}5.902 \\
(4.334)\end{array}$ & $\begin{array}{c}-298.645^{\star \star \star} \\
(43.081)\end{array}$ \\
\hline$\%$ Unemployed & $\begin{array}{l}-0.019 \\
(0.064)\end{array}$ & $\begin{array}{c}0.090 \\
(0.065)\end{array}$ & $\begin{array}{l}-5.752 \\
(5.120)\end{array}$ & $\begin{array}{c}-9.664 \\
(50.472)\end{array}$ \\
\hline \% Owner occupied & $\begin{array}{l}0.226^{\star \star \star} \\
(0.062)\end{array}$ & $\begin{array}{l}0.219^{\star \star \star} \\
(0.063)\end{array}$ & $\begin{array}{c}9.353 \\
(4.881)\end{array}$ & $\begin{array}{l}-30.243 \\
(48.655)\end{array}$ \\
\hline Constant & $\begin{array}{l}0.263^{\star \star \star} \\
(0.068)\end{array}$ & $\begin{array}{r}0.172^{*} \\
(0.069)\end{array}$ & $\begin{array}{c}0.413 \\
(5.375)\end{array}$ & $\begin{array}{l}166.427^{\star *} \\
(53.611)\end{array}$ \\
\hline Observations & 270 & 270 & 268 & 270 \\
\hline Adjusted R2 & 0.774 & 0.712 & 0.087 & 0.4 \\
\hline
\end{tabular}

Note: All dependent variables are continuous, and are modeled using ordinary least squares regression.

${ }^{*} \mathrm{p}<.05 ;{ }^{* *} \mathrm{p}<.01 ;{ }^{* * *} \mathrm{p}<.001$.

political participation by custodial citizens, whereby CSOs mitigate the demobilizing effects of criminal justice contact. We test this expectation at the community-level by interacting felony conviction rates and CSO density. Parallel to the results from our individual level analysis, political participation should be greater in communities where conviction rates are higher and the presence of CSOs are denser, compared to communities with lower CSO densities. Comparatively, lesser CSO densities and lower conviction rates should matter less for political participation outcomes at the community-level. While CSO density and conviction rates independently increase requests for nonemergency assistance, we do not observe in table 4 a statistically significant interactive association with nonvoting political participation or with voting.

Table 4

Interactive effect of conviction rates and CSO densities on voting and nonvoting political participation

\begin{tabular}{lcccc}
\hline & 2014 Voter Turnout & 2015 Voter Turnout & Meeting Attendance & 311 Calls \\
\hline Log (convictions) & -0.005 & -0.006 & 0.567 & $10.046^{\star \star \star}$ \\
log( CSOs) & $(0.004)$ & $(0.004)$ & $(0.378)$ & $(2.940)$ \\
& 0.004 & -0.003 & $0.847^{\star *}$ & $9.568^{\star \star}$ \\
Convictions ${ }^{\star}$ CSOs & $(0.004)$ & $(0.004)$ & $(0.326)$ & $(3.250)$ \\
Observations & -0.001 & -0.002 & -0.048 & 1.117 \\
Adjusted R2 & $(0.002)$ & $(0.002)$ & $(0.145)$ & $(1.275)$ \\
\hline
\end{tabular}

Notes: All dependent variables are continuous, and are modeled using ordinary least squares regression.

${ }^{*} p<.05 ;{ }^{* *} p<.01 ;{ }^{* \star *} p<.001$. Coefficients reflect fully specified models, located in table A12 of the online appendix. 
Figure 5 displays the marginal effects of CSO density, conviction rate, and the interaction between the two on each outcome of interest. These visualizations highlight that, independent of the felony conviction rate, the density of CSOs are positively related to nonvoting political participation. That is true, too, for the felony conviction rate in relation to 311 calls, regardless of CSO density. We interpret those results to mean that CSO density positively increases requests for nonemergency assistance in communities with either low or high felony conviction rates. Our interpretation is plausible, given that "organizational resources predict collective efficacy and [CSOs] produce externalities that foster collective action" in Chicago. ${ }^{124}$

However, we must reiterate two points. First, higher rates of 311 calls may result from greater needs for nonemergency assistance in high criminal justice contact (i.e., high felony conviction rate) communities. Second, higher attendance at police beat meetings may stem from greater degrees of police-community antagonisms, if policing is more concentrated, "hot spot" oriented, and aggressive. Put another way, higher rates of citizeninitiated contact with government in one form or another in communities with more custodial citizens could result from a need in such communities for greater attention from public officials, a need that may be absent in communities with fewer custodial citizens.

To address those potentialities, we employed a matching causal inference strategy that allowed us to compare the impact of CSO density among similarly situated communities that differ primarily by felony conviction rates. The strategy allowed us to compare low conviction rate communities to otherwise similarly situated high conviction rate communities. We describe the matching strategy and report results in full in the online appendix. Results from the matched analysis generally corroborate conclusions we drew from our analysis of the full sample before matching communities by rates of felony convictions. Specifically, greater CSO density is associated with greater requests for nonemergency assistance and attendance at police beat meetings among communities

\section{Figure 5}

\section{Conviction rate, CSO density, and participation among Chicago police beats}

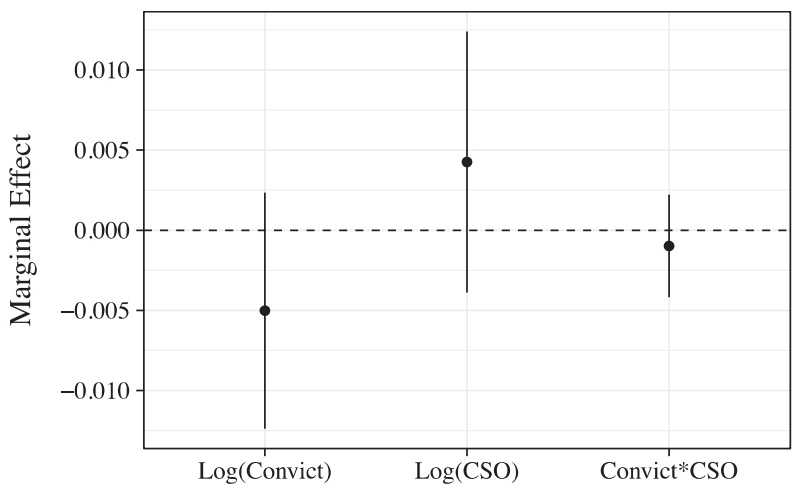

Model: 2014 Turnout

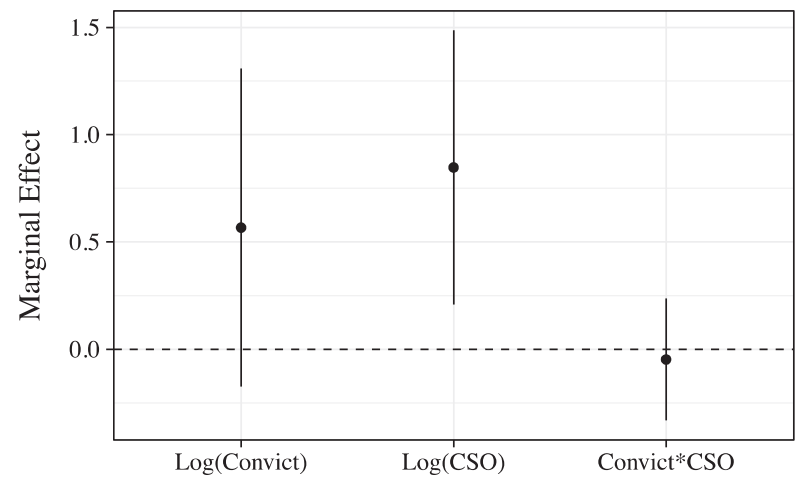

Model: Attendance at Police Beat Meetings

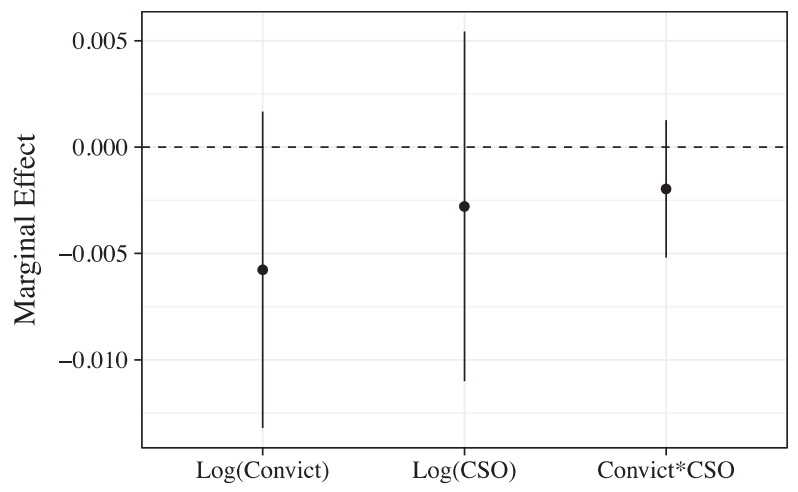

Model: 2015 Turnout

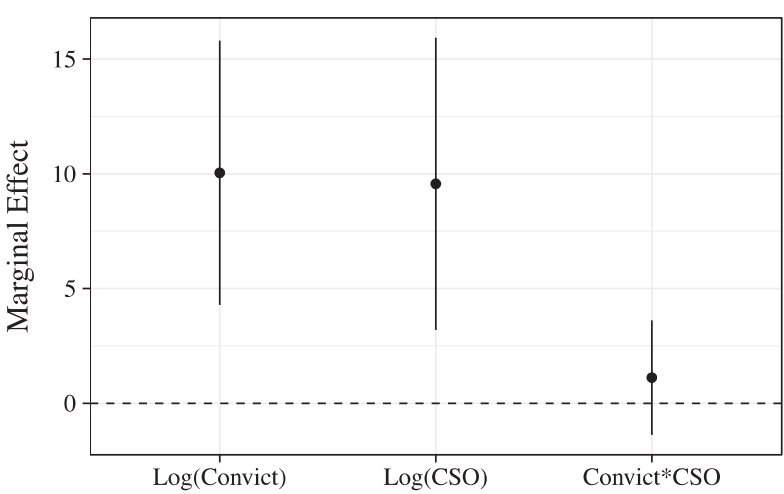

Model: 311 Calls

Notes: The marginal effect of conviction rate, CSOs per 1,000 in the population and their interaction on voting, attendance at police beat meetings, and requests for nonemergency assistance. Coefficient estimates reflect models presented in table 4. 


\begin{tabular}{|c|c|c|c|c|}
\hline & 2014 Voter Turnout & 2015 Voter Turnout & Meeting Attendance & 311 Calls \\
\hline Log (convictions per 1000 pop) & $\begin{array}{l}-0.022^{*} \\
(0.010)\end{array}$ & $\begin{array}{l}-0.042^{\star \star \star} \\
(0.010)\end{array}$ & $\begin{array}{c}0.610 \\
(0.495)\end{array}$ & $\begin{array}{l}-1.432 \\
(7.991)\end{array}$ \\
\hline Log (CSO per 1000 pop) & $\begin{array}{l}0.070^{\star \star *} \\
(0.007)\end{array}$ & $\begin{array}{c}0.003 \\
(0.008)\end{array}$ & $\begin{array}{c}0.880^{*} \\
(0.380)\end{array}$ & $\begin{array}{l}17.965^{\star *} \\
(6.087)\end{array}$ \\
\hline Convict $^{\star} \mathrm{CSO}$ & $\begin{array}{l}-0.055^{\star \star \star} \\
(0.016)\end{array}$ & $\begin{array}{l}-0.002 \\
(0.017)\end{array}$ & $\begin{array}{l}-0.386 \\
(0.813)\end{array}$ & $\begin{array}{l}-18.233 \\
(13.096)\end{array}$ \\
\hline $\begin{array}{l}\text { Observations } \\
\text { Adjusted R2 }\end{array}$ & 88 & 88 & $\begin{array}{l}88 \\
0.061\end{array}$ & $\begin{array}{l}88 \\
0.064\end{array}$ \\
\hline
\end{tabular}

Notes: All dependent variables are continuous, and modeled using ordinary least squares regression.

${ }^{*} p<.05 ;{ }^{* *} p<.01 ;{ }^{* *} p<.001$.

with either low or high felony conviction rates (refer to table 5 and figure 6).

To be clear, greater CSO density is associated with greater attendance at police beat meetings and requests for nonemergency assistance among low-conviction communities that are comparable in other ways to their high-conviction counterparts. Neither do conviction rates by themselves appear to impact nonvoting

Figure 6

Conviction rate, CSO density, and participation among matched police beats

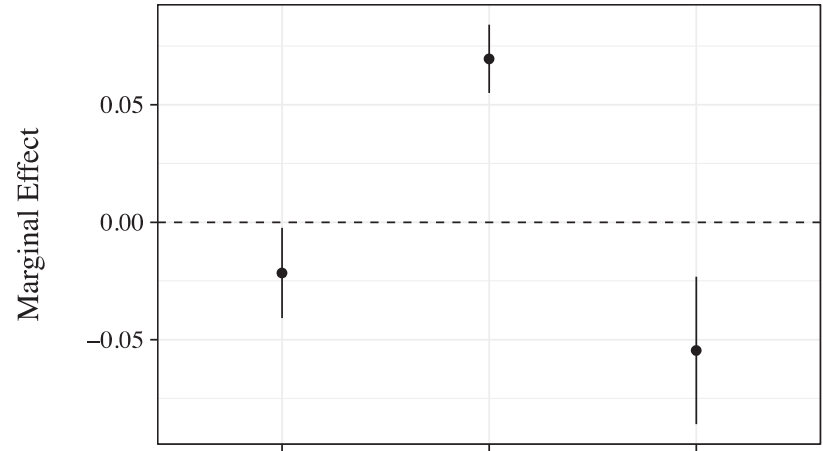

High Conviction $\quad \log (\mathrm{CSO}) \quad$ Convict*CSO

Model: 2014 Turnout

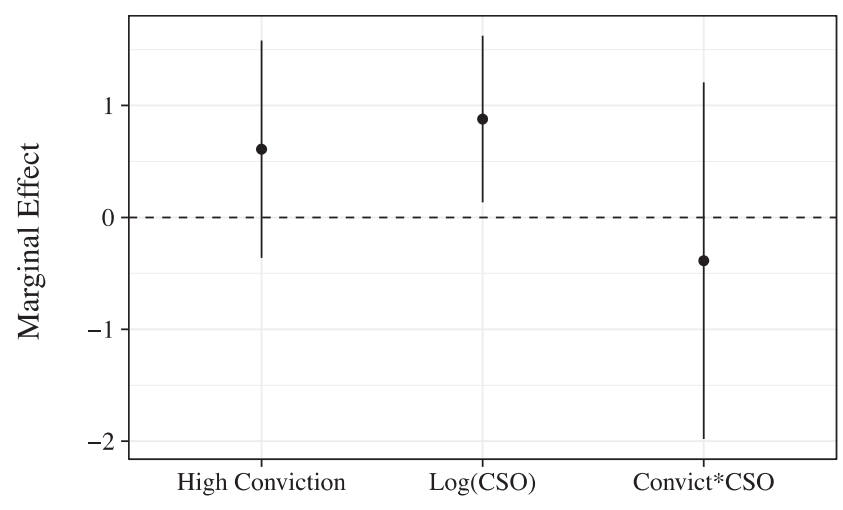

Model: Attendance at Police Beat Meetings

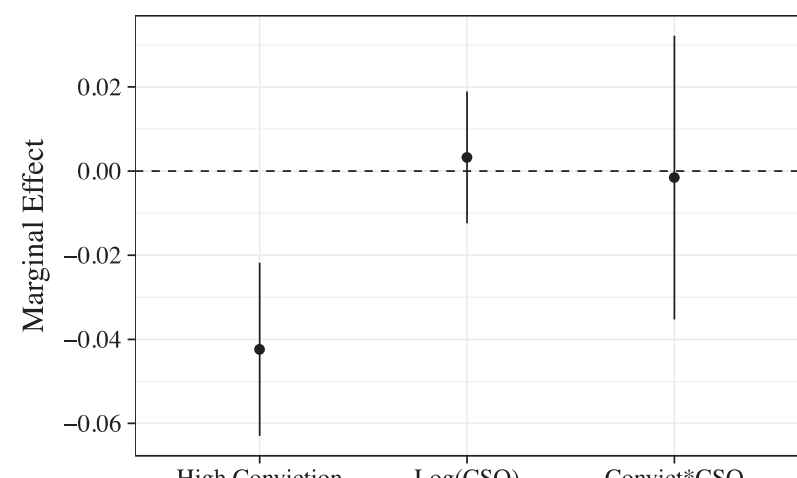

High Conviction $\quad \log (\mathrm{CSO}) \quad$ Convict $^{*} \mathrm{CSO}$

Model: 2015 Turnout

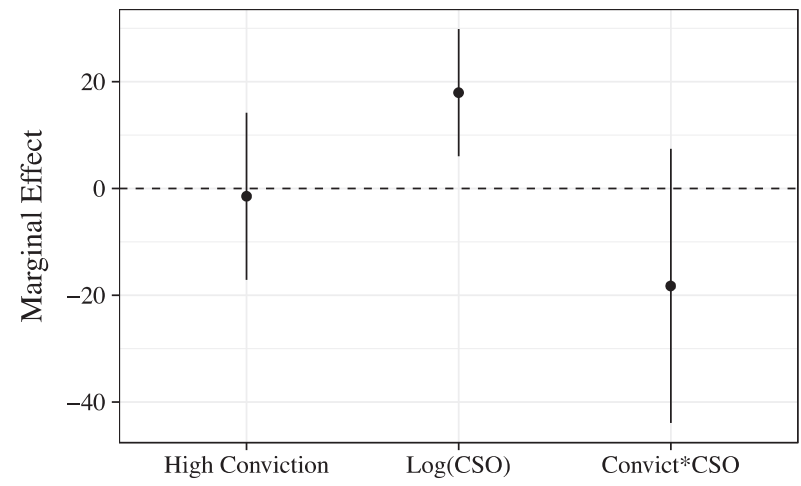

Model: 311 calls per 1000 pop

Notes: The marginal effects of conviction rate, CSOs per 1,000 in the population, and their interaction on voting, attendance at police beat meetings, and requests for nonemergency assistance, among matched police beats. Coefficient estimates reflect models presented in table 5 . 
political behavior, nor does CSO density operate differently for low- or high-conviction communities. The overriding factor influencing nonvoting political participation appears to be CSO density. Results from the matching strategy, then, confirm that our broader findings about CSO density and nonvoting political participation are not due to need alone in those communities.

Voting, however, is different. While increasing CSO density is associated with increasing voter turnout in high and low criminal justice contact communities in Chicago in 2014, the slope of increase is greater for low conviction communities than for high ones. This illuminates how we might interpret the effects of CSOs on nonvoting political participation in communities. Although the interaction term for convictions rates and CSO density does not achieve statistical significance for either meeting attendance or 311 calls per capita, as is the case with the results of the unmatched analysis presented earlier in table 4 and figure 5, the nature of the relationships are similar: CSO density increases nonvoting political behavior in high-conviction and low-conviction police beats, even if the size of the effect is larger in low-conviction communities.

Overall, CSOs are associated with more nonvoting political participation in high conviction communities, which parallels what we observed in the individual-level analysis, whereby personal connections to CSOs were associated with increased nonvoting political participation by custodial citizens. Also, contacting government, either through attendance at police beat meetings or making requests for nonemergency assistance, is about more than need. CSO density matters as there is an association between CSO density and increased nonvoting political participation, regardless of community-level conviction rates. However, as we generally observed in the individual-level analysis, where personal connections to CSOs were not associated with changes in voting, barriers may remain that hinder higher densities of CSOs from yielding greater degrees of voting by communities with high rates of criminal justice contact. ${ }^{125}$

\section{Discussion and Conclusion}

Studies of the influence of involuntary criminal justice contact on political participation reveal how unwanted interactions with the carceral state negatively influence political behavior by individuals and communities. Such studies, which mainly report on voting, suggest that criminal justice contact shifts many custodial citizens from political engagement to political quiescence, assuming they ever were politically active. Hence, involuntary criminal justice contact may yield "diluted political engagement," 126 which reduces the already low political influence of custodial citizens as individuals and collectives. ${ }^{127}$ But there is a bifurcation of participation by custodial citizens: custodial citizens may engage less as voters but their nonvoting political participation may not decline. In fact, the nonvoting political participation by custodial citizens may increase.

Nonvoting political participation by people who have had criminal justice contact, as our results suggest, is strongly associated with their personal connections to civil society organizations. This association may result from causal mechanisms inherent in specific forms of organizing and mobilization, but also service provision, by CSOs. When CSOs assist custodial citizens to solve problems arising from criminal justice contact (e.g., unemployment, precarious housing, lack of affordable legal assistance, etc.), they may implicitly or explicitly assist them-and their communities-to overcome efficacy and resource barriers to greater nonvoting (and sometimes voting) participation. ${ }^{128}$ Although our study was not designed to identify causality, future research on political participation-including nonvoting political participation-by custodial citizens that applies careful causal identification strategies are warranted. Additionally, it may be the case that particular types of CSOs matter more to increased (or reduced) political participation by custodial citizens and communities where more of them reside. That is undetermined. Insights from qualitative studies of custodial citizenship and participation, however, hint that some types of CSOs may prove more influential than others in shaping the engagement of people who have had criminal justice contact. ${ }^{129}$

Additionally, the observed relationship between personal connections to CSOs and increasing nonvoting political activities by custodial citizens, specifically individuals who experienced correctional control, is important to keep in mind. Nonvoting political participation is conventional political participation. ${ }^{130}$ Depending on the measure, nonvoting participation is more common than casting a ballot in the United States. ${ }^{131}$ Hence, the strength of the association between personal connections to CSOs and increasing nonvoting political participation among custodial citizens reminds us that they-even those whom the state has held tightest and longest via correctional control-are not that much different from noncustodial citizens when it comes to nonvoting political participation. Custodial citizens volunteer with campaigns, attend public meetings, make public-regarding contact with government via nonemergency call systems or letters and emails, recruit others to participate, and engage via a variety of participatory modes.

Accordingly, nonvoting political participation by custodial citizens and its breadth of activities, inclusive of electoral ones (e.g., volunteering with campaigns) and nonelectoral ones (e.g., petitioning), deserves as much attention as registering to vote and voting. To be blunt, social scientists, particularly political scientists, are overly concerned with the effect of criminal justice contact on voting, paying too little attention to political participation 
beyond voting by custodial citizens. Yet nonvoting political participation is perhaps more likely to strengthen the voice of custodial citizens in relation to distributive politics that condition their full citizenship.

Furthermore, much of the CSO activity in relation to political organizing and mobilizing of custodial citizens is and will be for individual and collective goods, not the ballot. In increasing numbers of cities and states, the restoration of social and civil rights to custodial citizens without them is the primary attention of CSOs concerned about the democratic effects of criminal justice contact. Their work is marked by advocacy and lobbying campaigns, not voter registration and turnout drives, to remove the bars on access to social welfare benefits (e.g., food stamps and public housing) and to open labor markets through "ban the box" (i.e., removal of screener questions from job applications that may reduce employment of people with criminal records). ${ }^{132}$ Additionally, a lot of organizing of custodial citizens is less about individuals and more about their communities in the name of universal improvement and community development.

Are we calling for political scientists and others to abandon the study of voting by custodial citizens? No. Normative, empirical, and substantive reasons remain for us to keep studying custodial citizens as slack resources before, during, and after elections. ${ }^{133}$ Certainly, political mobilization of custodial citizens for greater democratic participation obligates attention to the restoration of voting rights and other electoral matters. There are, for example, significant activities underway in Florida to immediately re-enfranchise all custodial citizens without records of violent crime and to return the ballot to prison inmates in California, Massachusetts, and New Jersey.

Nevertheless, political participation of custodial citizens as voters may not increase, regardless of the success of those voting-rights restoration campaigns. It also may not increase despite personal connections to civil society organizations as we observed in our Chicago research. The results failed to show statistically significant relationships between criminal justice contact, personal connections to CSOs, and registering to vote and voting at both the individual and aggregate levels. More concretely, the negative relationship between criminal justice contact and voting may endure even by custodial citizens in communities where voting rights restoration happens immediately after incarceration and where CSOs are dense and personal connections to them are strong.

Before we conclude, it is worth reiterating the descriptive character of our study. We are not able to draw conclusions about the causal pathways of criminal justice contact, CSO connections, and political participation. Not only do we lack administrative data on individual level connections to CSOs and participatory activities beyond voting, our individual-level data is cross-sectional and from a survey subject to selection bias. It may be, for instance, that individuals who are connected to CSOs are also the sort of people likely to participate at high levels. Previous research suggests otherwise, however, and demonstrates that nonpolitical institutions are instrumental to cultivating the political skills and interests important to participation. Yet we are unsure about the exact nature of this relationship from cross-sectional, observational data. While our use of aggregate data, which ameliorates sampling and response bias, produced results that generally support the claim that CSOs increase participation in all kinds of communities, we observed that the magnitude of the civil society potential for increased civic voluntarism in communities with lower rates of custodial citizens was greater than what we observed in communities with higher rates of custodial citizens. Cumulative disadvantage and institutional barriers to participation, which exacerbate each other, construct obstacles for custodial citizens and their communities to full participation in political life. In the absence of better data, however, we can only postulate about how CSO connections shape civic education, access, and engagement, and whether variation in civic voluntarism by custodial citizens is indicative of relative disempowerment or strength.

Still, our findings disrupt the characterization that communities where criminal justice contact is prevalent are beleaguered, possessing weak capacities for personal and collective efficacy, which undermine engagement of their custodial residents in the polis. For example, our study suggests that citizen-initiated contact with government can be greater in communities with higher rates of residents with criminal convictions than in communities with lower rates of residents with criminal convictions. Thus, communities with high rates of criminal justice contact may not participate less in all forms of action, at least when the civic voluntarism in question includes behaviors beyond the frequency of voting.

Also, our research encourages political scientists to rethink how we understand and measure the political lives of marginalized people and their communities. By widening our theoretical and empirical gazes beyond "the electoral-representative dynamics that have become the taken-for-granted object of our attention" ${ }^{134}$ we can better observe how custodial citizens and their communities do politics, as well as better observe how their political behavior may bear on and be shaped by the institutions and distributive politics of the carceral state.

Finally, echoing Majic, "it is . . imperative that we examine nonprofit organizations more closely and identify the ways they may engage in civic life, especially if we are concerned with expanding inclusion and justice through and in the democratic political process." ${ }^{135}$ This is especially true in the age of the carceral state and its expanding custodial citizenry. Research into the broader effects, particularly participatory paradoxes, that the 
American carceral state produces for civil society must continue, inclusive of the ways civil society organizations foster (or inhibit) the political participation of custodial citizens and their communities.

\section{Notes}

1 "Criminal justice contact" means here involuntary contact with the criminal justice system.

2 Gottschalk 2016.

3 Bruch and Soss 2018; Shedd 2015; Rios 2011.

4 Lerman and Weaver 2014a.

5 National Center for Victims of Crime 2016; Enns 2016.

6 U.S. Bureau of Justice Statistics 1993; U.S. Bureau of Justice Statistics 2018

7 Clark 2018.

8 Jacobs 2015, 1 and n. 4.

9 U.S. Bureau of Justice Statistics 2012.

10 Jacobs 2015, xi.

11 Pager 2007; Travis and Waul 2003.

12 Comfort 2016; Travis and Waul 2003.

13 Clear 2007.

14 Gottschalk 2016.

15 Skocpol 2017.

16 Wheelock 2011; King and Mauer 2004; Smith 2004.

17 Steinacker 2003.

18 Manza and Uggen 2004, 2006.

19 Thorpe 2015; Walker et al. 2017.

20 Petit 2012.

21 Sances and You 2017; Harris 2016; Katzenstein and Waller 2015; U.S. Department of Justice 2015.

22 The democratic effects of juvenile criminal justice contact on the civic voluntarism of youth and during adulthood merit future investigation. Surveillance and policing of youth in the United States (e.g., police in schools) are common and youth interactions with the criminal justice systems for juveniles and adults are widespread; see Shedd 2015, Rios 2011. Juvenile criminal justice contact can affect subsequent adult criminal justice contact. It is plausible that youth contact with punitive institutions of juvenile criminal justice provides "formative political experience" as punitive institutions of schools do for youth; see Bruch and Soss 2018. If so, juvenile criminal justice contact may have negative consequences for juvenile civic voluntarism and subsequent adult civic voluntarism.

23 Weaver and Lerman 2010; Hjalmarsson and Lopez 2010; Lerman and Weaver 2014a; Kang and Dawes 2017; Laniyonu 2018.

24 Weaver and Lerman 2010; Lerman and Weaver 2014a, 2014b; Kang and Dawes 2017; Laniyonu 2018.
25 Some types of vehicle and pedestrian stops by police officers, as well as all types of correctional control, are associated with greater distrust and less confidence in government and lower perceptions of public institutions as legitimate; Clear 2007; Weaver and Lerman 2010; Lerman and Weaver 2014a; Epp, Maynard-Moody, and Haider-Markel 2014.

26 Weaver and Lerman 2010, 818.

27 E.g., Hull 2006; Manza and Uggen 2006; Katzenstein, Ibrahim, and Rubin 2010; Weaver and Lerman 2010; Burch 2013; Lerman and Weaver 2014a; Meredith and Morse 2014; Muller and Shrage 2014; Walker 2014; White 2015; Meredith and Morse 2015; Gerber et al. 2015, 2017; Howard 2017; Kang and Dawes 2017.

28 Soss and Weaver 2017, 567.

29 Ibid, 565.

30 See, e.g., Hull 2006; Howard 2017; Dilts 2014; Weaver and Lerman 2010; Lerman and Weaver 2014a, 2014b; White 2015; Burch 2013; Manza and Uggen 2006; Bruch, Marx Ferree, and Soss 2010; Lee, Porter, and Comfort, 2014; Muller and Schrage 2014; Walker 2014; Gerber et al. 2017; Kang and Dawes 2017; Laniyonu 2018.

31 Burch 2013; Owens 2014

32 E.g., Cohen and Rodgers 1995; Warren 2001; Putnam 2000; Fung 2003; Majic 2011; LeRoux and Krawczyk, 2014; Han 2016; Fyall and Allard 2017.

33 Personal connections to CSOs by juveniles with criminal justice contact may also mitigate some of the negative political effects of juvenile criminal justice contact and influence civic voluntarism in adulthood. However, that is for future study.

34 Han 2016.

35 Schlozman 2002, 439; Verba, Schlozman, and Brady 1995.

36 Rosenstone and Hansen 2003, 2.

37 Mettler and Soss 2004, 56.

38 Peffley and Hurwitz 2010; Wilson, Owens, and Davis 2015; Enns 2016.

39 Owens and Smith 2012; Kaufman 2015; Miller 2014.

40 Mettler and Soss 2004, 56.

41 Fairchild 1977, 298.

42 Tyler, Fagan, and Geller 2014; Epp, Maynard-Moody, and Haider-Markel 2014; Justice and Meares 2014; Miller 2015.

43 Weaver and Lerman 2010; Lerman and Weaver 2014a; Kang and Dawes 2017; Haselswerdt 2009; Hjalmarsson and Lopez 2010; Meredith and Morse 2014, 2015; Gerber et al., 2015; White 2015. However, a provocative study using administrative data on pre-incarceration and post-release voting in Pennsylvania between 2008 and 2012 concludes "spending time in prison has almost no effect on 
voting”; Gerber et al. 2017, 1131-32. Nonetheless, as its authors note, "that incarceration per se does not appear to cause a large reduction in [voting] suggests that scholars should follow the path of recent research that examines how citizen preferences and behaviors are shaped by lower-level contact [e.g., detentions for questioning] with these other elements of the state."

44 Lerman and Weaver 2014a, 220-21. Furthermore, there is evidence that noncustodial citizens in romantic relationships with custodial citizens are less likely to vote; Lee, Porter, and Comfort 2014; Sugie 2015.

45 Clear 2007.

46 Burch 2013; Laniyonu 2018.

47 Owens 2014, 258.

48 Lerman and Weaver 2014a; Wildeman, Hacker, and Weaver, 2014; Burch 2013.

49 Owens 2014; Lerman and Weaver 2014a; Muller and Schrage 2014; Justice and Meares 2014.

50 Weaver and Lerman 2010; Lerman and Weaver 2014a; Walker 2014; Lee, Porter, and Comfort 2014.

51 Verba, Schlozman, and Brady 1995.

52 Han 2016, 296.

53 Berry, Portney, and Thomson 1993, 12.

54 De Tocqueville 2002; de Beaumont and de Tocqueville 1979.

55 Sampson 2012, 179.

56 Putnam 2000.

57 Han 2014, 8.

58 Putnam 2000.

59 Kaufman 2015; Miller 2014.

60 Fyall and Allard 2017; Berry 2003.

61 Han 2014; Rosenstone and Hansen 2003; Verba, Schlozman, and Brady 1995. Many individuals, however, involve themselves in organizations without "pressure" from CSOs. Instead of waiting on the organizing and mobilizing of CSOs, they rely on self-motivation. They may have orientations or predispositions to participate regardless of any activities by or engagement with CSOs. For them, recruitment by CSOs in not necessary to their participation, which is something the authors of the classic Civic Voluntarism Model acknowledge.

62 Schneider and Ingram 1997; Cohen 1999; Strolovitch 2007.

63 Burch 2013, ch. 6.

64 De Tocqueville 2002; Putnam 2000; Han 2016.

65 Marwell 2004; Berry, Portney, and Thomson 1993.

66 Harris 1999; Marwell 2004; Owens 2007; Fyall and Allard 2017.

67 Harris 2001; Owens 2007.

68 Levi 2004; Marwell 2004; Owens 2007.

69 Cohen and Rogers 1995; Warren 2000; Putnam 2000.

70 Han 2009, 2014, 2016.

71 Verba, Schlozman, and Brady 1995, 17-18.
72 Harris 2001; Wong 2009; Graauw 2016.

73 Skocpol 1990, 456.

74 Verba, Schlozman, and Brady 1995; Rosenstone and Hansen 2003; Han 2009, 2014.

75 Rosenstone and Hansen 2003, 83-84.

76 Berry, Portney, and Thomson 1993; Verba, Schlozman, and Brady 1995; Han, 2009, 2014, 2016; Harris, 2001.

77 Rosenstone and Hansen 2003, 32; Verba, Schlozman, and Brady 1995.

78 Marwell 2004; Owens 2007.

79 Wong 2006; Barreto et al. 2009; Majic 2011; LeRoux and Krawczyk 2014; Graauw 2016; García Bedolla and Michelson 2012; Warren 2001.

80 Harris 2001; Wong 2009; Majic 2011; García Bedolla and Michelson 2012; LeRoux and Krawczyk 2014; Graauw 2016.

81 Berry, Portney, and Thomson 1993, 95-97.

82 Fung 2003; Cohen 2004; Majic 2011.

83 Examples include EPOCA (Ex-Prisoners and Prisoners Organizing for Community Advancement) in Worcester, MA; V.O.T.E. (Voice of the Ex-Offender) in New Orleans, EXPO (Ex-Prisoners Organizing) in Milwaukee, Wisconsin; and the California, Texas, and North Carolina chapters of All of Us or None; Owens 2014; Kaufman 2015; Flores and Cossyleon 2016.

84 Owens 2014; Williams 2015; Flores and Cossyleon 2016.

85 Sampson 2012, 77.

86 Ibid., 21.

87 Sampson and Loeffler 2010; Visher, Yahner, and La Vigne 2010.

88 Commonly used datasets such as the National Longitudinal Study of Adolescent Health and the Fragile Families and Child Well Being Study are two-decades old and include truncated age cohorts. More recent data from the 2006 African American Men's Survey and the 2016 American National Election Studies include measures of criminal justice contact but the former only includes voter registration as political participation and the latter excludes measures of connections to CSOs.

89 Gerber et al. 2017.

90 Skogan 2016.

91 Gerber et al. 2017; Weaver and Lerman 2010; Lerman and Weaver 2014a; Lee, Porter, and Comfort 2014; Walker 2014.

92 Sampson 2012, 190.

93 Skogan and Hartnett 1997.

94 Skogan 2016.

95 Ibid.

96 Sampson 2012, 208.

97 Rosenstone and Hansen 2003, 86. 
98 That is higher than the turnout of registered voters (73\%) in Cook County elections that year, according to the Illinois State Board of Elections. CAS respondents may have over-reported voting, which is common in public opinion surveys because of the social desirability associated with voting. Selection bias may also explain the high rate of reported voting political participation in the CAS. Individuals who chose to participate in the CAS could be more civic-minded-and more likely to vote-than the general population. Either type of bias could skew empirical results in our favor. As we describe in our appendix, we took steps to address issues related to selection bias in survey data. While we cannot correct for response bias, abstaining from other types of political activities, like attending a protest or signing petitions, does not carry with it the stigma of failing in one's duty as a citizen associated with nonvoting; Holbrook et al 2010, Persson and Solevid 2013.

99 Descriptive statistics for all variables in both datasets are in the online appendix, which reports the descriptive statistics for the CAS (tables A1-A2) and the aggregate dataset (tables A4-A5).

100 Sampling bias in surveys leads to samples unrepresentative of the overall population. Sampling weights are constructed to address this issue. However, individuals with criminal justice contact often are unlike the general population, differing, for instance, on dimensions of race, gender, and age. The subsample of Chicago Area Study respondents with criminal justice contact likely differs from the general population under correctional contact in the Chicago metropolitan area. Exact, current and complete demographic information on metropolitan Chicago's custodial citizenry, especially members of the correctional population, is unavailable. In lieu of better demographic data, we compare Chicago Area Study respondents with criminal justice contact to Cook County Jail admissions in 2011 and the Illinois prison population in 2010. The subsample of custodial citizens in the Chicago Area Study is less black, more Latino, more female, slightly older, and more likely to be married than Cook County jailees and Illinois prison inmates. Full comparisons of their characteristics are available in the online appendix. The difference in characteristics likely biases statistical findings in favor of our prediction. This may be a limitation of our analysis. Barring better sampling strategies for social surveys of the behavior of custodial citizens, which we strongly advocate, there is little that political scientists can do to alter the nature of our samples.

101 For more information about the data and its collection, see http://convictions.smartchicagoapps. org/\#five-years-of-data. Additionally, the online appendix describes the felony conviction data and other data we considered using to complement or substitute felony convictions as our aggregate measure of criminal justice contact.

102 The distribution of felony convictions had a minimum value of zero and a maximum value of 33 . The lower quartile fell below 2.5 felony convictions.

103 Sampson 2012, ch. 8.

104 Ibid.

105 Ibid.

106 See http://nccs-data.urban.org/data.php?ds=bmf and https://www.irs.gov/charities-non-profits/ exempt-organizations-business-master-file-extracteo-bmf.

107 For more information on the IRS classifications, see https://www.irs.gov/charities-non-profits/ types-of-tax-exempt-organizations.

108 The minimum was .032 CSOs and the maximum was 152 CSOs.

109 "More than any kind of activity, contacting [government and public officials] is distinguished by the control the participant can exercise over timing of the activity and the content of the message"; Verba, Schlozman, and Brady 1995, 89.

110 Although the creation of CAPS increased the opportunity structure for political engagement, our time frame corresponded with "the period of the greatest decline in overall attendance levels" at police beat meetings due to municipal budget cuts of CAPS and the redeployment of police officers. Skogan 2016, 7. Thus, the CAPS meeting data provides a hard test for our theory.

111 Lerman and Weaver 2014b; O'Brien 2016; White and Trump, 2016; O'Brien et al. 2017.

112 The 311 call systems are a simple way of citizen-initiated contact with government, especially to report public problems such as potholes and property blight. They provide a "low-transactioncost access to government that have been shown to instill a sense of trust and offer the promise of increased bureaucratic responsiveness," while fostering individual and collective efficacy; Minkoff 2016, 212.

113 O'Brien et al. 2017, 323.

114 Lerman and Weaver 2014b.

115 The online appendix details our construction of the aggregate dataset.

116 Although our key independent and dependent variables include both conventional and novel ones, some are imperfect. We use voter turnout estimates within police beats, calculated by simple area weighting. Felony convictions exclude criminal justice contact that does not result in arrests, charges without conviction, and convictions for misdemeanors. The CSO density measure includes 
a variety of nonprofit organizations, inclusive of those that do and do not target custodial citizens. They range from religious congregations like the Chicago Foursquare Church to the local affiliate of federated community organizing groups such as the Gamaliel Foundation, to labor organizations such as Women in Aviation International. The CSO density measure also excludes organizations that possess tax-exempt status but are not required to register with the IRS (e.g., small religious congregations). While our CSO density measure is blunt, its noise should bias empirical analyses toward null results. To control for various sources of bias that may influence conviction rates, civic engagement, and CSO density, we leverage data on housing tenure, age and racial compositions, educational attainment, poverty, and unemployment from the U.S. Census Bureau.

117 We model nonvoting behavior with Poisson regression, as noted in table 1 . If the distribution of the dependent variable is over dispersed, it is appropriate to evaluate the data with an alternative model (e.g., negative binomial regression or a quasi-Poisson model). Tests for dispersion, noted in table 1 and table 2, resulted in no evidence of data overdispersion. For more on this point, refer to the online appendix.

118 Walker 2014; Lee, Porter and Comfort 2014.

119 Lerman and Weaver 2010; Lee, Porter and Comfort 2014; Walker 2014.

120 Tests of the robustness of our models are available from the online appendix; See figure A1 and tables A9-A11.

121 Our null findings may result from our measure of voting, which is self-reported. Because of social desirability, respondents often misreport their voting histories on surveys; Holbrook and Krosnick 2010. Even when self-reported voting is not correlated with criminal justice contact and positively correlated with nonvoting political participation, contact may be negatively associated with voting when measured by validated voter records; Walker 2014. We may also have null findings because voting is modeled among registered voters. Thus, individuals in the sample with connections to the criminal justice system have already overcome a significant barrier to voting. We are cautious in interpreting our null result that criminal justice contact is not associated with voting in Chicago.

122 Sampson and Loeffler 2010.

123 White and Trump 2016; Lerman and Weaver $2014 \mathrm{~b}$.

124 Sampson 2012, 208.

125 Burch 2013.

126 Weaver and Lerman 2010, 824; Burch 2013, 2014; Lerman and Weaver 2014a, 2014b; Laniyonu 2018.
127 Owens 2014; Miller and Stuart 2017.

128 Owens 2014; Flores and Cossyleon 2016; Williams 2015; Kaufman 2015; Miller 2014.

129 Maruna 2001; Owens 2014; Flores and Cossyleon 2016; Williams 2015; Kaufman 2015; Miller 2014.

130 Verba, Schlozman, and Brady 1995; Han 2016.

131 Verba, Schlozman, and Brady 1995.

132 Owens 2014; Owens and Smith 2012.

133 E.g., Katzenstein, Ibrahim, and Rubin 2010; Dilts 2014; Lerman and Weaver 2014a; Kang and Dawes 2017; Gerber et al. 2015, 2017.

134 Soss and Weaver 2016, 75.

135 Majic 2011, 832.

\section{Supplementary Materials}

Appendix

- Description of the Chicago Area Study Data

- Description of the Aggregate Data

- Analysis of the Chicago Area Study

- Analysis of the Supplemental Aggregate Data

https://doi.org/10.1017/S1537592718002074

\section{References}

Barreto, Matt A., Sylvia Manzano, Ricardo Ramirez, and Kathy Rim. 2009. "Mobilization, Participation, and Solidaridad: Latino Participation in the 2006 Immigration Protest Rallies." Urban Affairs Review 44(5): 736-64.

Beaumont, Gustave de and Alexis de Tocqueville. 1979. On the Penitentiary System in the United States and Its Application in France. Carbondale: Southern Illinois University Press.

Berry, Jeffrey M. 2003. A Voice for Nonprofits. Washington, DC: Brookings Institution Press.

Berry, Jeffrey M., Kent E. Portney, and Ken Thomson. 1993. The Rebirth of Urban Democracy. Washington, DC: Brookings Institution Press.

Bruch, Sarah K., Myra Marx Ferree, and Joe Soss. 2010. "From Policy to Polity: Democracy, Paternalism, and the Incorporation of Disadvantaged Citizens." American Sociological Review 75(2): 205-26.

Bruch, Sarah K. and Joe Soss. 2018. "Schooling as a Formative Political Experience: Authority Relations and the Education of Citizens." Perspectives on Politics 16(1): 36-57.

Burch, Traci. 2013. Trading Democracy for Justice: Criminal Convictions and the Decline of Neighborhood Political Participation. Chicago: University of Chicago Press. 2014. "The Effects of Imprisonment and Community Supervision on Neighborhood Political Participation in North Carolina." The ANNALS of the 
American Academy of Political and Social Science 651(1): 184-201.

Clark, Dan. 2017. "How Many U.S. Adults Have a Criminal Record? Depends on How You Define It." Politifact, New York. Available at http://www.politifact. com/new-york/statements/2017/aug/18/andrewcuomo/yes-one-three-us-adults-have-criminal-record/.

Clear, Todd. 2007. Imprisoning Communities: How Mass Incarceration Makes Disadvantaged Neighborhoods Worse. New York: Oxford University Press.

Cohen, Cathy. 1999. The Boundaries of Blackness: AIDS and the Breakdown of Black Politics. Chicago: University of Chicago Press.

2004. "Deviance as Resistance: A New Research

Agenda for the Study of Black Politics.” Du Bois Review:

Social Science Research on Race 1(1): 27-45.

Cohen, Joshua and Joel Rogers. 1995. Associations and Democracy. London: Verso Books.

Comfort, Megan. 2016. “'A Twenty-Hour-a-Day Job': The Impact of Frequent Low-Level Criminal Justice Involvement on Family Life." The ANNALS of the American Academy of Political and Social Science 665(1): 63-79.

Dilts, Andrew. 2014. Punishment and Inclusion: Race, Membership, and the Limits of American Liberalism. New York: Fordham University Press.

Enns, Peter. 2016. Incarceration Nation: How the United States Became the Most Punitive Democracy in the World. New York: Cambridge University Press.

Epp, Charles, Steven Maynard-Moody, and Donald Haider-Markel. 2014. Pulled Over: How Police Stops Define Race and Citizenship. Chicago: University of Chicago Press.

Fairchild, Erika. 1977. "Politicization of the Criminal Offender.” Criminology 15(3): 287-318.

Filindra, Alexandra, Noah Kaplan and Maria Krysan. 2014. "2014 Chicago Area Study." University of Illinois Chicago.

Flores, Edward and Jennifer Cossyleon. 2016. "I Went Through It So You Don't Have To': Faith-Based Community Organizing for the Formerly Incarcerated." Journal for the Scientific Study of Religion 55(4): 662-76.

Fung, Archon. 2003. "Association and Democracy: Between Theories, Hopes, and Realities." Annual Review of Sociology 29: 515-39.

Fyall, Rachel and Scott Allard. 2017. "Nonprofits and Political Activity: A Joint Consideration of the Political Activities, Programs, and Organizational Characteristics of Social Service Nonprofits." Human Service Organizations 41(3): 275-300.

García Bedolla, Lisa and Melissa Michelson. 2012. Mobilizing Inclusion: Redefining Citizenship through Get-Out-the-Vote Campaigns. New Haven, CT: Yale University Press.

Gerber, Alan S., Gregory A. Huber, Marc Meredith, Daniel R. Biggers, and David J. Hendry. 2015.
"Can Incarcerated Felons Be (Re)integrated into the Political System? Results from a Field Experiment." American Journal of Political Science 59(4): 912-26. . 2017. "Does Incarceration Reduce Voting? Evidence about the Political Consequences of Spending Time in Prison." Journal of Politics 79(4): 1130-46.

Gottschalk, Marie. 2016. Caught: The Prison State and the Lockdown of American Politics. Princeton, NJ: Princeton University Press.

Graauw, Els de. 2016 Making Immigrant Rights Real: Nonprofits and the Politics of Integration in San Francisco. Ithaca, NY: Cornell University Press.

Han, Hahrie. 2009. Moved to Action: Motivation, Participation, and Inequality in American Politics. Stanford, CA: Stanford University Press.

- 2014. How Organizations Develop Activists: Civic Associations and Leadership in the 21st Century. New York: Oxford University Press.

_. 2016. "The Organizational Roots of Political Activism: Field Experiments on Creating a Relational Context." American Political Science Review 110(2): 296-307.

Harris, Fredrick. 2001. Something Within: Religion in African-American Political Activism. New York: Oxford University Press.

Harris, Alexes. 2016. A Pound of Flesh: Monetary Sanctions and Punishment for the Poor. New York: Russell Sage Foundation.

Haselswerdt, Michael. 2009. "Con Job: An Estimate of Ex-Felon Voter Turnout Using Document-Based Data." Social Science Quarterly 90(2): 262-73.

Hjalmarsson, Randi and Mark Lopez. 2010. "The Voting Behavior of Young Disenfranchised Felons." American Law and Economics Review 12(2): 356-93.

Howard, Marc Morjé. 2017. Unusually Cruel: Prisons, Punishment, and the Real American Exceptionalism. New York: Oxford University Press.

Holbrook, Allyson and Jon Krosnick. 2010. "Social Desirability Bias in Voter Turnout Reports." Public Opinion Quarterly 74(1): 37-67.

Hull, Elizabeth. 2006. The Disenfranchisement of Ex-Felons. Philadelphia, PA: Temple University Press.

Jacobs, James. 2015. The Eternal Criminal Record. Cambridge: Harvard University Press.

Justice, Benjamin and Tracey L. Meares. 2014. "How the Criminal Justice System Educates Citizens." The ANNALS of the American Academy of Political and Social Science 651(1): 159-77.

Kang, Woo Chang and Christopher T. Dawes. 2017. "The Electoral Effect of Stop-and-Frisk." Available at https://papers.ssrn.com/sol3/papers.cfm? abstract_id=3000561, accessed March 20, 2018.

Katzenstein, Mary Fainsod, Leila Ibrahim, and Katherine Rubin. 2010. "The Dark Side of American Liberalism 
and Felony Disenfranchisement." Perspectives on Politics 8(4): 1035-54.

Katzenstein, Mary Fainsod and Maureen Waller. 2015.

"Taxing the Poor: Incarceration, Poverty Governance, and the Seizure of Family Resources." Perspectives on Politics 13(3): 638-56.

Kaufman, Nicole. 2015. "Prisoner Incorporation: The Work of the State and Nongovernmental Organizations." Theoretical Criminology 19(4): 534-53.

King, Ryan and Marc Mauer. 2004. "The Vanishing Black Electorate: Felony Disenfranchisement in Atlanta, Georgia." Washington, DC: The Sentencing Project.

Laniyonu, Ayobami. 2018. "Police, Politics and Participation: The Effect of Police Exposure on Political Participation in the United Kingdom.” The British Journal of Criminology. Available at https://doi.org/ 10.1093/bjc/azy003.

Lee, Hedwig, Lauren Porter, and Megan Comfort. 2014. "Consequences of Family Member Incarceration: Impacts on Civic Participation and Perceptions of the Legitimacy and Fairness of Government." The ANNALS of the American Academy of Political and Social Science 651(1): 44-73.

Lerman, Amy and Vesla Weaver. 2014a. Arresting Citizenship: The Democratic Consequences of American Crime Control. Chicago: University of Chicago Press.

_ 2014b. "Staying out of Sight? Concentrated Policing and Local Political Action." The ANNALS of the American Academy of Political and Social Science 651(1): 202-19.

LeRoux, Kelly and Kelly Krawczyk. 2014. "Can Nonprofit Organizations Increase Voter Turnout? Findings from an Agency-Based Voter Mobilization Experiment." Nonprofit and Voluntary Sector Quarterly 43(2): 272-92.

Levi, Margaret. 2003. "Organizing Power: The Prospects for an American Labor Movement." Perspectives on Politics 1(1): 45-68.

Majic, Samantha. 2011. "Serving Sex Workers and Promoting Democratic Engagement: Rethinking Nonprofits' Role in American Civic and Political Life." Perspectives on Politics 9(4): 821-39.

Manza, Jeff and Christopher Uggen. 2004. "Punishment and Democracy: Disenfranchisement of Nonincarcerated Felons in the United States," Perspectives on Politics 2(3): 491-505.

- 2006. Locked Out: Felon Disenfranchisement and American Democracy. New York: Oxford University Press.

Maruna, Shad. 2001. Making Good: How Ex-Convicts Reform and Rebuild Their Lives. Washington, DC: American Psychological Association.

Marwell, Nicole P. 2004. "Privatizing the Welfare State: Nonprofit Community-Based Organizations as
Political Actors." American Sociological Review 69(2): 262-91.

Meredith, Marc and Michael Morse. 2014. "Do Voting Rights Notification Laws Increase Ex-Felon Turnout?" The ANNALS of the American Academy of Political and Social Science 651(1): 220-49.

2015. "The Politics of the Restoration of Ex-Felon Voting Rights: The Case of Iowa." Quarterly Journal of Political Science 10(1): 41-100.

Mettler, Suzanne and Joe Soss. 2004. "The Consequences of Public Policy for Democratic Citizenship: Bridging Policy Studies and Mass Politics." Perspectives on Politics 2(1): 55-73.

Miller, Joshua. 2015. "Democracy and Education Behind Bars." Perspectives on Politics 13(3): 714-21.

Miller, Reuben. 2014. "Devolving the Carceral State: Race, Prisoner Reentry and the Micro-Politics of Urban Poverty Management." Punishment and Society 16(3): 305-35.

Miller, Reuben and Forrest Stuart. 2017. "Carceral Citizenship: Race, Rights and Responsibility in the Age of Mass Supervision.” Theoretical Criminology 21(4): 532-48.

Minkoff, Scott. 2016. "NYC 311: A Tract-Level Analysis of Citizen-Government Contacting in New York City." Urban Affairs Review 52(2): 211-46.

Muller, Christopher and Daniel R. Schrage. 2014. "Mass Imprisonment and Trust in the Law." The ANNALS of the American Academy of Political and Social Science 651(1): 139-58.

National Center for Victims of Crime. 2016. "Crime Trends.” Available at https://ovc.ncjrs.gov/ncvrw2016/ content/section-6/PDF/2016NCVRW_CrimeTrends508.pdf, accessed February 21, 2018.

O’Brien, Daniel. 2016. “311 Hotlines, Territoriality, and the Collaborative Maintenance of the Urban Commons: Examining the Intersection of a Coproduction Policy and Evolved Human Behavior." Evolutionary Behavioral Sciences 10(2): 123-41.

O’Brien, Daniel, Dietmar Offenhuber, Jessica Baldwin-Philippi, Melissa Sands, and Eric Gordon. 2017. "Uncharted Territoriality in Coproduction: The Motivations for 311 Reporting." Journal of Public Administration Research and Theory 27(2): 320-35.

Owens, Michael Leo. 2007. God and Government in the Ghetto: The Politics of Church-State Collaboration in Black America. Chicago: University of Chicago Press. . 2014. "Ex-Felons' Organization- Based Political Work for Carceral Reforms." The ANNALS of the American Academy of Political and Social Science 651(1): 256-65.

Owens, Michael Leo and Adrienne R. Smith. 2012. "'Deviants' and Democracy: Punitive Policy Designs 
and the Social Rights of Felons as Citizens." American Politics Research 40(3): 531-67.

Pager, Devah. 2007. Marked: Race, Crime, and Finding Work in an Era of Mass Incarceration. Chicago:

University of Chicago Press.

Peffley, Mark and Jon Hurwitz. 2010. Justice in America: The Separate Realities of Blacks and Whites. New York: Cambridge University Press.

Persson, Mikael and Maria Solevid. 2013. "Measuring Political Participation: Testing Social Desirability Bias in a Web-survey Experiment." International Journal of Public Opinion Research 26(1): 98-112.

Petit, Becky. 2012. Invisible Men: Mass Incarceration and the Myth of Black Progress. New York: Russell Sage Foundation.

Putnam, Robert. 2000. Bowling Alone: The Collapse and Revival of American Community. New York: Simon \& Schuster.

Rios, Victor. 2011. Punished: Policing the Lives of Black and Latino Boys. New York: New York University Press.

Rosenstone, Steven J. and John Mark Hansen. 2003. Mobilization, Participation, and Democracy in America. New York: Longman.

Sampson, Robert. 2012. Great American City: Chicago and the Enduring Neighborhood Effect. Chicago: University of Chicago Press.

Sampson, Robert and Charles Loeffler. 2010.

"Punishment's Place: The Local Concentration of Mass Incarceration." Daedalus 139(3): 20-31.

Sances, Michael W. and Hye Young You. 2017. "Who Pays for Government? Descriptive Representation and Exploitative Revenue Sources." Journal of Politics 79(3): 1090-94.

Schlozman, Kay Lehman. 2002. "Citizen Participation in America: What Do We Know? Why Do We Care?" In Political Science: The State of the Discipline, ed. Ira Katznelson and Helen Milner. New York: W.W. Norton \& Company.

Schlozman, Kay Lehman, Sidney Veba, and Henry E. Brady. 1999. "Civic Participation and the Equality Problem." In Civic Engagement in American Democracy, ed. Theda Skocpol, and Morris Fiorina. Washington, DC: Brookings Institution Press and Russell Sage Foundation.

Schneider, Anne and Helen Ingram. 1997. Policy Design for Democracy. Lawrence: University Press of Kansas.

Shedd, Carla. 2015. Unequal City: Race, Schools, and Perceptions of Justice. New York: Russell Sage Foundation.

Skocpol, Michael. 2017. "The Emerging Constitutional Law of Prison Gerrymandering." Stanford Law Review 69(5): 1473-539.

Skocpol, Theda. 1990. "Sustainable Social Policy: Fighting Poverty Without Poverty Programs." The American Prospect 2: 58-70.
1999. "Advocates without Members: The Recent Transformation of American Civic Life." In Civic Engagement in American Democracy, ed. Theda Skocpol, and Morris Fiorina. Washington, DC: Brookings Institution Press and Russell Sage Foundation.

Skocpol, Theda and Morris Fiorina, eds. 1999. Civic Engagement in American Democracy. Washington, DC: Brookings Institution Press and Russell Sage Foundation. Skogan, Wesley. 2016. "What Happened to Community Policing?" Unpublished manuscript.

Skogan, Wesley and Susan Hartnett. 1997. Community Policing, Chicago Style. New York: Oxford University Press.

Smith, Kevin B. 2004. "The Politics of Punishment: Evaluating Political Explanations of Incarceration Rates." Journal of Politics 66(3): 925-38.

Soss, Joe and Vesla Weaver. 2017. "Police Are Our Government: Politics, Political Science, and the Policing of Race-Class Subjugated Communities." Annual Review of Political Science 20: 565-91.

. 2016. "Learning from Ferguson: Welfare, Criminal Justice and the Political Science of Race and Class." Washington, DC: American Political Science Association.

Steinacker, Andrea. 2003. "The Prisoner 's Campaign: Felony Disenfranchisement Laws and the Right to Hold Public Office." BYU Law Review 2003(2): 801-28.

Strolovitch, Dara. 2007. Affirmative Advocacy: Race, Class, and Gender in Interest Group Politics. Chicago: University of Chicago Press.

Sugie, Naomi. 2015. "Chilling Effects: Diminished Political Participation among Partners of Formerly Incarcerated Men.” Social Problems 62(4): 550-71.

Thorpe, Rebecca. 2015. "Perverse Politics: The Persistence of Mass Imprisonment in the Twenty-First Century." Perspectives on Politics 13(3): 618-37.

Tocqueville, Alexis de. 2002. Democracy in America. Chicago: University of Chicago Press.

Travis, Jeremy and Michelle Waul. 2003. Prisoners Once Removed: The Impact of Incarceration and Reentry on Children, Families, and Communities. Washington, DC: Urban Institute Press.

Tyler, Tom, Jeffrey Fagan, and Amanda Geller. 2014. "Street Stops and Police Legitimacy: Teachable Moments in Young Urban Men's Legal Socialization." Journal of Empirical Legal Studies 11(4): 751-85.

Uggen, Christopher and Jeff Manza. 2002. "Democratic Contraction? Political Consequences of Felon Disenfranchisement in the United States." American Sociological Review 67(6): 777-803.

U.S. Bureau of Justice Statistics. 1993. Survey of Criminal History Information Systems. Washington, DC: U.S. Department of Justice.

. 2012. "One in 34 U.S. Adults Under Correctional Supervision in 2011, Lowest Rate Since 2000.” 
Available at https://www.bjs.gov/content/pub/press/ cpus11ppus11pr.cfm, accessed February 19, 2018. . 2018. Survey of State Criminal History Information Systems. Washington, DC: U.S. Department of Justice. U.S. Department of Justice. 2015. The Ferguson Report: Department of Justice Investigation of the Ferguson Police Department. New York: Free Press.

Verba, Sidney, Kay Schlozman, and Henry Brady. 1995. Voice and Equality: Civic Voluntarism in American Politics. Cambridge, MA: Harvard University Press.

Visher, Christy, Jennifer Yahner, and Nancy La Vigne. 2010. Life after Prison: Tracking the Experiences of Male Prisoners Returning to Chicago, Cleveland, and Houston. Washington, DC: Urban Institute.

Walker, Hannah. 2014. "Extending the Effects of the Carceral State: Proximal Contact, Political Participation, and Race." Political Research Quarterly 67(4): 809-22.

Walker, Hannah, Rebecca U. Thorpe, Emily K. Christensen, and J. P. Anderson. 2017. "The Hidden Subsidies of Rural Prisons: Race, Space and the Politics of Cumulative Disadvantage." Punishment and Society 19(4): 393-416.

Warren, Mark. 2000. Democracy and Association. Princeton, NJ: Princeton University Press.

— 2001. Dry Bones Rattling: Community Building to Revitalize American Democracy. Princeton, NJ:

Princeton University Press.
Weaver, Vesla and Amy Lerman. 2010. "Political Consequences of the Carceral State." American Political Science Review 104(4): 817-33.

Wheelock, Darren. 2011. "A Jury of One's 'Peers': The Racial Impact of Felon Jury Exclusion in Georgia." Justice System Journal 32(3): 335-59.

White, Ariel. 2015. "Misdemeanor Disenfranchisement? The Demobilizing Effects of Brief Jail Spells on Potential Voters." Unpublished paper.

White, Ariel and Kris-Stella Trump. 2016. "The Promises and Pitfalls of 311 Data." Urban Affairs Review 54(4): 794-823.

Wildeman, Christopher, Jacob Hacker, and Vesla Weaver. 2014. "Detaining Democracy? Criminal Justice and American Civic Life." The ANNALS of the American Academy of Political and Social Science 651(1): 6-21.

Williams, Quintin. 2015. "Returning Citizens? The Path from Prison to Politics among the Formerly Incarcerated." Master's thesis, Loyola University, Chicago.

Wilson, David, Michael Leo Owens, and Darren Davis. 2015. "How Racial Attitudes and Ideology Affect Political Rights for Felons." Du Bois Review: Social Science Research on Race 12(1): 73-93.

Wong, Janelle. 2006. Democracy's Promise: Immigrants and American Civic Institutions. Ann Arbor: University of Michigan Press. 